Article

\title{
Double Stage Double Output DC-DC Converters for High Voltage Loads in Fuel Cell Vehicles
}

\author{
Mahajan Sagar Bhaskar, Sanjeevikumar Padmanaban * ${ }^{(1)}$ and Jens Bo Holm-Nielsen \\ Center for Bioenergy and Green Engineering, Department of Energy Technology, Aalborg University, \\ 6700 Esbjerg, Denmark; sagar24.mahajan@gmail.com (M.S.B.); jhn@et.aau.dk (J.B.H.-N.) \\ * Correspondence: san@et.aau.dk
}

Received: 1 July 2019; Accepted: 19 September 2019; Published: 26 September 2019

\begin{abstract}
This article aims to enhance the output voltage magnitude of fuel cells (FCs), since the actual generation is low. The traditional technique is too complicated and has a cascaded or parallel connection solution to achieve high voltage for multiple loads in vehicles. In this case, electronic power converters are a viable solution with compact size and cost. Hence, double or multiple output DC-DC converters with high voltage step up are required to feed multiple high voltage loads at the same time. In this article, novel double stage double output (DSDO) DC-DC converters are formulated to feed multiple high voltage loads of FC vehicular system. Four DSDO DC-DC converters called DSDO L-L, DSDO L-2L, DSDO L-2LC, and DSDO L-2LC are developed in this research work and all the converters are derived based on the arrangement of different reactive networks. The primary power circuitry, conceptual operation, and output voltage gain derivation are given in detail with valid proof. The proposed converters are compared with possible parallel combinations of conventional converters and recently available configuration. Comprehensive numerical simulation and experimental prototype results show that our theoretical predictions are valid and that the configuration is applicable for real time application in FC technologies for 'more-electric vehicles'.
\end{abstract}

Keywords: DC-DC; double stage; double output; fuel cell; step-up; vehicular system; X-Y converter family

\section{Introduction}

In electric grid, hybrid 'more-electric vehicles', automobile high-intensity discharge headlamps, uninterruptible power supply, and luxury loads application multiport and multilevel power converters popular solutions [1-4]. Some advanced predictive control based on the multilevel converter is also proposed for energy storage [5,6]. Fuel cells have many features, including compatibility, size, and modularity $[7,8]$. However, the amalgamation of series and parallel FCs is not a suitable solution for generating high DC voltage/current. Trade-off loss increases the cost of the system and requires a large space. Furthermore, the major obstacles facing FC technology are durability, low generated voltage, and to fulfill the voltage demand of high voltage loads in FC vehicles. In such cases, power electronic DC-DC converters with high voltage conversion ratios and high efficiency play a pivotal control role [9-12]. Theoretically, a moderate or high output voltage is obtained from a traditional boost converter by operating in an extreme duty cycle. Adverse effects at extreme duty ratio lead to reduced controllability, increased switching losses, high conduction losses, large current ripple, high current and voltage ratings, and reverse diode recovery problems [13-16]. Consequently, traditional DC-DC converters are not suitable candidates for FC electric vehicle applications.

Previous research has achieved high voltage conversion ratio by using a cascaded traditional boost converter configuration. However, cascaded converter configurations have low efficiency and high cost due to the increased number of high voltage/current rating semiconductor devices and reactive 
elements $[17,18]$. Further, for implementation, they need complex control logic and increased driver modules to protect and control the semiconductor devices. Quadratic boost converters achieve a high voltage conversion ratio, but high current/voltage rating components/devices and the internal resistance of the inductors limits the output voltage [19]. Multistage diode/capacitor-based DC-DC converters have been proposed to achieve high voltage gain [20-24]. However, multiple discharging/charging loops of the capacitors lead to increased conduction loss, cost, and size, and reduced efficiency due to their parasitic nature. Converters have been proposed to get multiple outputs from a single input source by using push-pull, half-bridge, full-bridge, and fly-back converter topologies [25-27]. In all cases, high voltage is obtained with a high transformer rating on the primary side. Therefore, these converters cannot provide a proper solution for low weight/cost applications.

The parallel configurations of traditional converters such as boost, buck-boost, Cuk, single ended primary inductance converter (SEPIC), and ZETA can be possible solutions to achieve multiple outputs. The power circuitry of possible configurations without common front-end structure are shown in Figure 1a-e. These configurations provide two outputs using two different control switches. However, the voltage gain is not significantly improved, even when using a large number of components and devices. Furthermore, in order to reduce the component or device counts, common front-end structure can be a solution, as shown in Figure $1 \mathrm{f}-\mathrm{j}$. These configurations provide dual output using common front-end structures. However, only a few input side components are used, the device count is reduced, and the voltage gain is limited. Moreover, the current rating of the components is increased due to the common structure. In order to reduce the component count, hybrid converters are another possible solution. Moreover, hybrid Cuk, SEPIC, and ZETA converter configurations can achieve multiple outputs. A combination of Cuk and SEPIC converter structure was employed in [28]. Figure 2a shows the SEPIC-Cuk converter circuitry with common front-end design and dual output. A combination of ZETA and buck-boost converter structure was employed in [29].

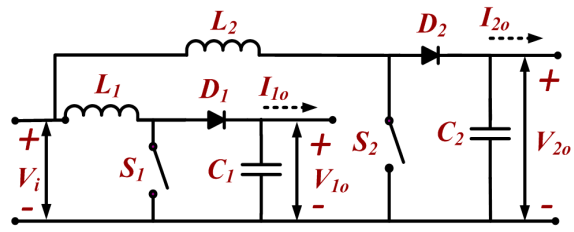

(a)

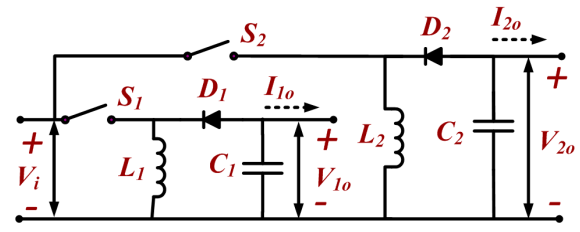

(b)

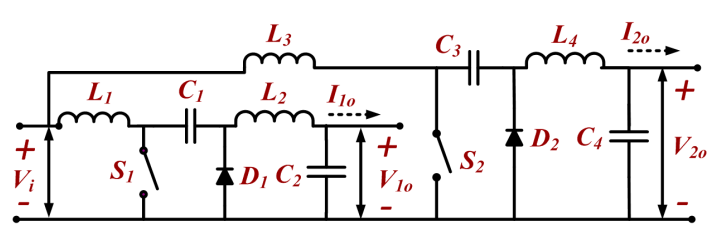

(c)

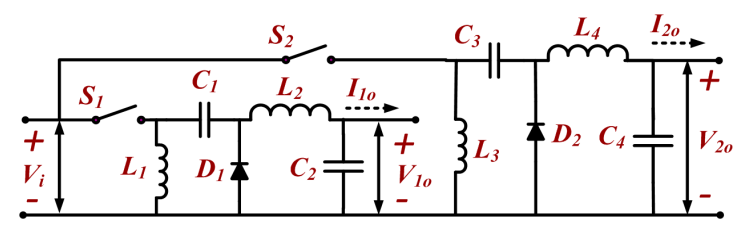

(e)

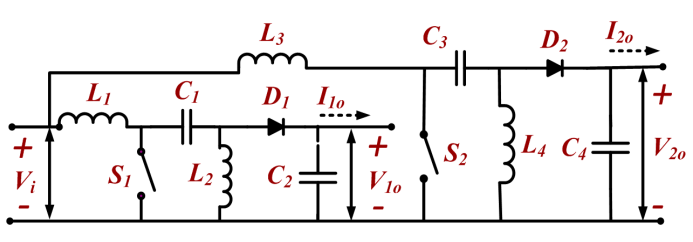

(d)

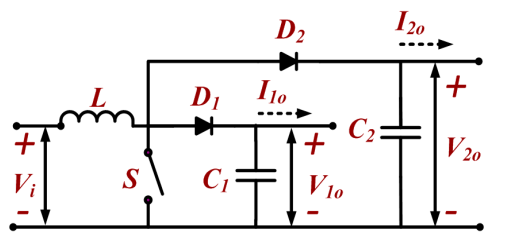

$(\mathbf{f})$

Figure 1. Cont. 


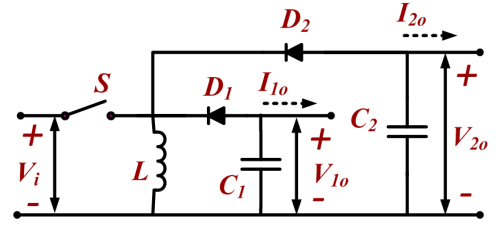

(g)

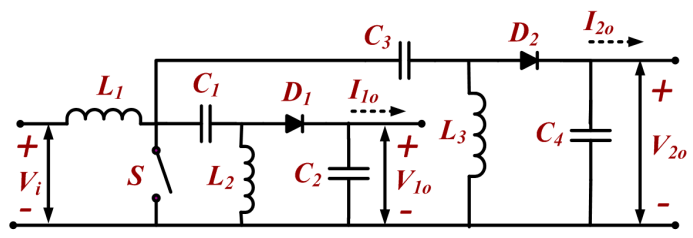

(i)

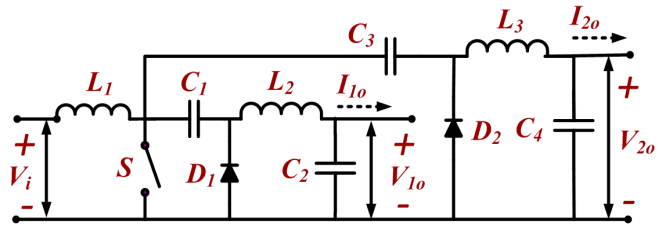

(h)

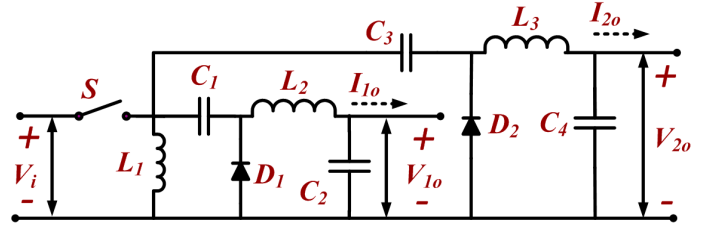

(j)

Figure 1. Power circuit of conventional parallel converters: (a) boost-boost converter; (b) buckboost-buck-boost converter; (c) Cuk-Cuk converter; (d) single ended primary inductance converter (SEPIC)-SEPIC converter; (e) ZETA-ZETA converter; (f) boost-boost converter with common front-end structure; (g) buck-boost-buck-boost converter with common front end structure; (h) Cuk-Cuk converter with common front-end structure; (i) SEPIC-SEPIC converter with common front-end structure; (j) ZETA-ZETA converter with common front-end structure.

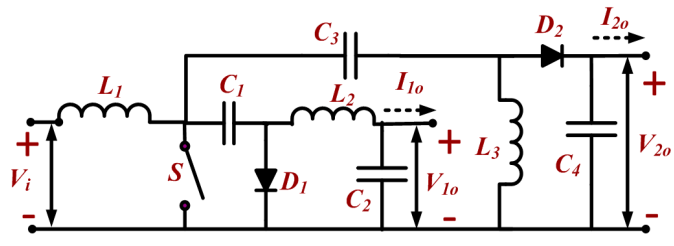

(a)

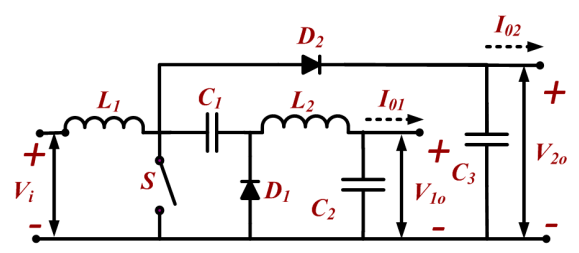

(c)

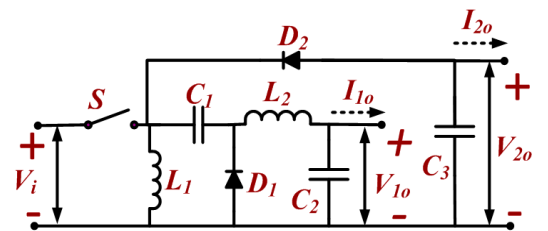

(b)

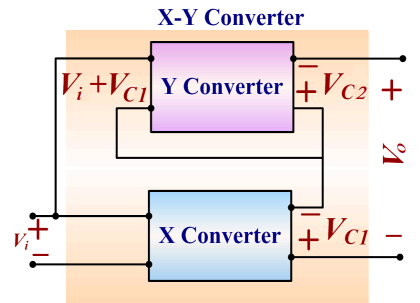

(d)

Figure 2. Power circuit of (a) SEPIC-Cuk converter, (b) ZETA-Buck-boost converter, (c) boost-Cuk converter; (d) Basic block diagram of the $\mathrm{X}-\mathrm{Y}$ converter family.

Figure $2 \mathrm{~b}$ shows the circuitry of a ZETA-Buck-boost converter with common front-end structure and two outputs. The combination of Cuk and boost converters is employed in [30]. The circuitry of a boost-Cuk converter with common front-end and two outputs is shown in Figure 2c. The voltage conversion ratio of these topologies is limited. Furthermore, efforts have been made to reduce the switching and to obtain multiple outputs [31-33]. However, these converters have low voltage conversion ratio and are more suitable for low-power applications. The "X-Y converter family" has been proposed for high voltage output and has single switching and a capacitor stack at the output side [34-38]. The block diagram of the X-Y converter family is depicted in Figure $2 d$. Notable, in $X Y$ converters, the $X$ converter is directly connected to the input supply, and the $Y$ converter is fed from the output voltage of the $X$ converter. The output voltage of an $X-Y$ converter is the sum of the output voltages of the $X$ and $Y$ converters. In order to achieve multiple outputs and high voltage conversion ratio, this article contributes the following: 
- The L-Y converters, i.e., an expanded member of the XY converter family that feeds power to two different high voltage loads. At same time, the proposed converter provides high voltage conversion ratio. A diagram of a typical fuel-cell vehicle (FCV) with a DSDO converter is shown Figure 3, where low FC voltage is fed to two high voltage loads.

- Four new original converter configurations (DSDO L-L, DSDO L-2L, DSDO, L-2LC, and DSDO, $\mathrm{L}-2 \mathrm{LC} \mathrm{C}_{\mathrm{m}}$ ) are derived from a single switch.

- The modes of operation, characteristics waveform, and voltage gain analysis for each proposed configuration are discussed in detail.

- The performance of the proposed converters is validated through numerical simulation and experimental prototype results.

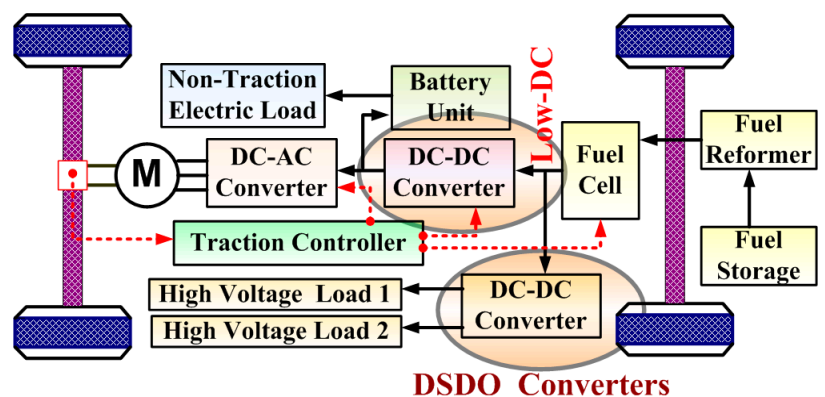

Figure 3. Typical structure of fuel cell (FC) vehicle with double stage double output (DSDO) converters.

\section{Double Stage Double Output Converters}

\subsection{DSDO L-L Converter}

Figure 4 depicts the power circuit of a DSDO L-L converter. In a DSDO L-L converter, a single switch $S$ and input voltage $V_{i}$ are arranged in two stages. Two L-L converters are employed to obtain dual output voltage. The capacitors $C_{1}, C_{2}$, inductors $L_{1}, L_{2}$, and diodes $D_{1}, D_{2}, D_{3}$ are elements of L-L converter-1. The capacitors $C_{1}^{\prime}{ }_{1}, C^{\prime}{ }_{2}$, inductors $L_{1}^{\prime}, L_{2}^{\prime}$, and diodes $D_{1}^{\prime}{ }_{1}, D^{\prime}{ }_{2}, D^{\prime}{ }_{3}$ are elements of $\mathrm{L}-\mathrm{L}$ converter-2. The stage- 1 and stage- $1^{\prime}$ voltages are obtained across capacitors $C_{1}$ and $C^{\prime}{ }_{1}$, respectively. The stage- 2 and stage- $2^{\prime}$ voltages are obtained across capacitors $C_{2}$ and $C_{2}^{\prime}$, respectively. The load $R_{1 o}$ is connected across capacitors $C_{1}, \mathrm{C} 2$, and load $R_{20}$ is connected across capacitors $C_{1}^{\prime}$ and $C_{2}^{\prime}$ to achieve double output voltages, i.e., $V_{10}$ and $V_{20}$, from a single source input $\left(V_{i}\right)$ as shown in Figure 4 .

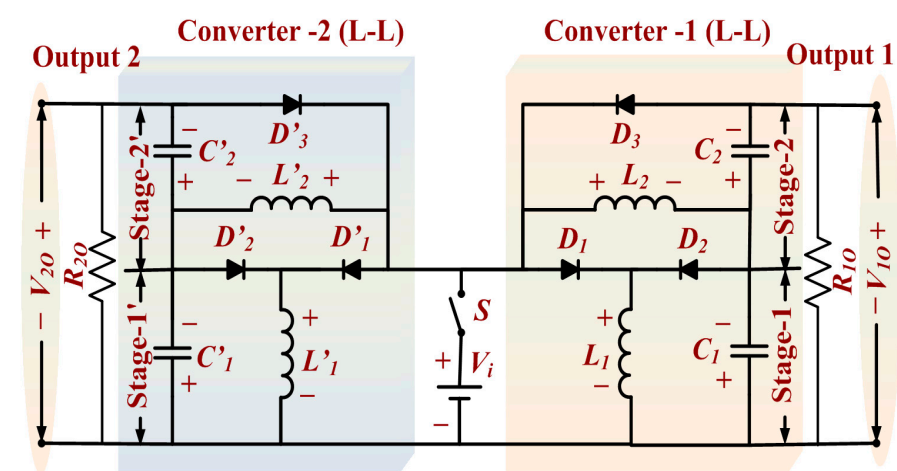

Figure 4. Power circuit of a DSDO L-L converter.

The DSDO L-L converter operates in two modes: switch S turn-ON and another when switch S turn-OFF. Figure 5 shows the characteristics of inductor voltage and current obtained for one switching cycle. Time zone A-B describes the $\mathrm{ON}$ time of the switch and time zone $\mathrm{B}-\mathrm{C}$ describes the OFF time. The equivalent circuit for turn-ON mode is shown in Figure 6a. In this mode, inductor $L_{1}$ is magnetized 
through switch $S$ and diode $D_{1}$ from the input power of voltage $V_{i}$. At the same time, input voltage $V_{i}$ and the voltage across capacitor $C_{1}$ magnetizes the inductor $L_{2}$. Total energy stored in capacitors $C_{1}$ and $C_{2}$ provide load $R_{10}$. Inductor $L_{1}^{\prime}$ is magnetized through switch $S$ and diode $D_{1}^{\prime}$ by the input voltage $V_{i}$. At the same time, input voltage $V_{i}$ and voltage across capacitor $C^{\prime}{ }_{1}$ magnetizes inductor $L_{2}^{\prime}$. The energy is delivered to load $R_{20}$ by capacitors $C^{\prime}{ }_{1}$ and $C^{\prime}{ }_{2}$. During turn-ON, capacitors $C_{1}, C_{1}^{\prime}$, $C_{2}$, and $C_{2}^{\prime}$ are discharged, and inductors $L_{1}, L_{1}^{\prime}, L_{2}$, and $L_{2}^{\prime}$ are magnetized. Throughout this mode, diodes $D_{1}, D^{\prime}{ }_{1}$ are forward biased and diodes $D_{2}, D_{3}, D_{2}^{\prime}, D_{3}^{\prime}$ are reverse biased.

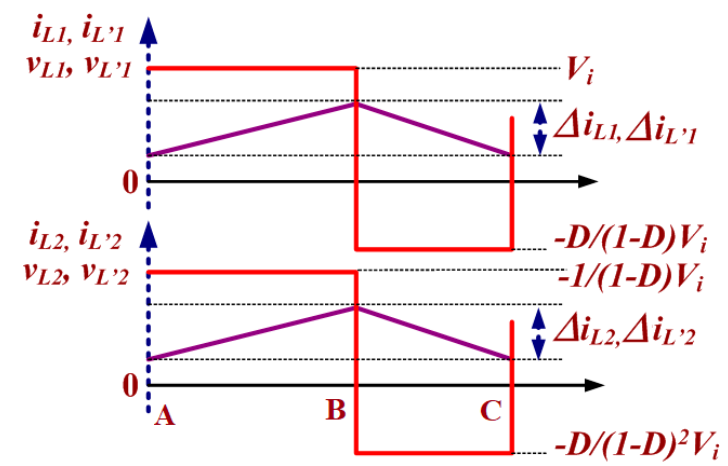

Figure 5. Waveforms of inductor voltages and currents for a DSDO L-L converter.

The voltages across inductors can be obtained as follows,

$$
V_{L 1}=V_{i} ; V_{L 2}=V_{C 1}+V_{i} ; V_{L / 1}=V_{i} ; V_{L / 2}=V_{C / 1}+V_{i}
$$

The equivalent circuit for turn-OFF mode is shown in Figure $6 \mathrm{~b}$. In this mode, the capacitor $C_{1}$ is charged by stored energy in the inductor $L_{1}$ through diode $D_{2}$. At the same time, capacitor $C_{2}$ is charged by stored energy in the inductor $L_{2}$ through diode $D_{3}$. Energy is provided to load $R_{10}$ by the connection of inductors $L_{1}$ and $L_{2}$. Capacitor $C^{\prime}{ }_{1}$ is charged from stored energy in inductor $L_{1}^{\prime}$ through diode $D_{2}^{\prime}$. At the same time, capacitor $C_{2}^{\prime}$ is charged from stored energy in inductor $L_{2}^{\prime}$ through diode $D^{\prime}{ }_{3}$. Energy is provided to load $R_{20}$ by connection of inductors $L_{1}^{\prime}{ }_{1}$ and $L_{2}^{\prime}$. In turn-OFF mode, capacitors $C_{1}, C_{1}^{\prime}, C_{2}$, and $C_{2}^{\prime}$ are charged and inductors $L_{1}, L_{1}^{\prime}, L_{2}$, and $L_{2}^{\prime}$ are demagnetized. In this mode, diodes $D_{1}, D^{\prime}{ }_{1}$ are reverse biased and diodes $D_{2}, D_{3}, D_{2}^{\prime}$, and $D^{\prime}{ }_{3}$ are forward biased.

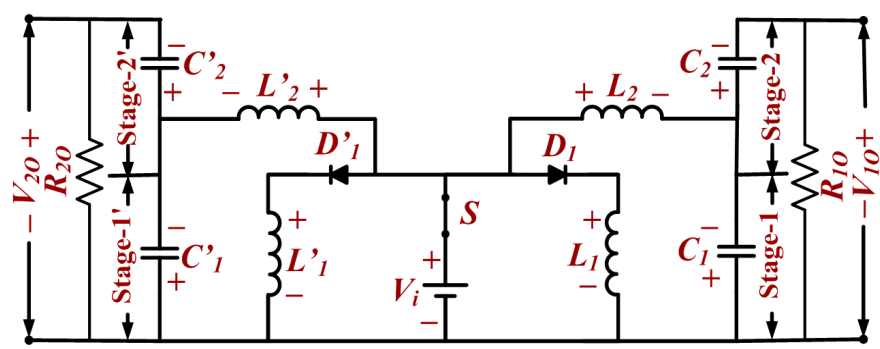

(a)

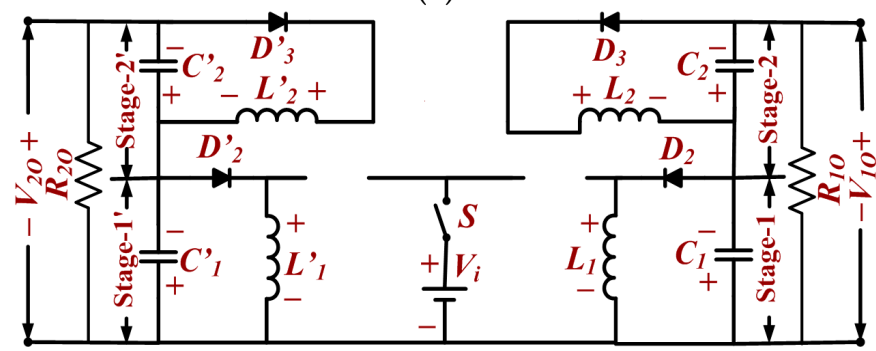

(b)

Figure 6. Equivalent circuitry of a DSDO L-L converter: (a) ON mode; (b) OFF mode. 
The voltages across inductors can be obtained as follows,

$$
V_{L 1}=-V_{C 1} ; V_{L 2}=-V_{C 2} ; V_{L / 1}=-V_{C, 1} ; V_{L / 2}=-V_{C / 2}
$$

The output voltages $V_{10}$ and $V_{20}$ are obtained as follows,

$$
\left.\begin{array}{l}
\frac{V_{C 1}}{V_{i}}=\frac{V_{C 1}}{V_{i}}=D(1-D)^{-1}, \frac{V_{C 2}}{V_{i}}=\frac{V_{C 12}}{V_{i}}=D(1-D)^{-2} \\
V_{1 o}=V_{2 o}=-V_{i} \times\left(D(1-D)^{-1}+D(1-D)^{-2}\right)
\end{array}\right\}
$$

\section{2. $D S D O L-2 L$ Converter}

Figure 7 illustrates the power circuit of a DSDO L-2L converter. A single switch $S$ and input voltage $V_{i}$ are employed with two-stage L-2L converters to obtain dual output voltage. The capacitors $C_{1}, C_{2}$ inductors $L_{1}, L_{2}, L_{3}$, and diodes $D_{1}, D_{2}, \ldots$, and $D_{6}$ are elements of $\mathrm{L}-2 \mathrm{~L}$ converter- 1 . The capacitors $C^{\prime}{ }_{1}, C^{\prime}{ }_{2}$, inductors $L_{1}^{\prime}, L_{2}^{\prime}{ }_{2}, L^{\prime}{ }_{3}$, and diodes $D_{1}^{\prime}{ }_{1}, D^{\prime}{ }_{2}, \ldots$, and $D^{\prime}{ }_{6}$ are elements of $\mathrm{L}-2 \mathrm{~L}$ converter-2. The stage- 1 and stage- 2 voltages are taken across capacitors $C_{1}$ and $C_{2}$, respectively. The stage- $1^{\prime}$ and stage- $2^{\prime}$ voltages are taken across capacitors $C^{\prime}{ }_{1}$ and $C_{2}^{\prime}$, respectively. The two output voltages are taken across capacitors $C_{1}+C_{2}$ and $C_{1}^{\prime}+C_{2}^{\prime}$, respectively. The load $R_{10}$ is connected across capacitors $C_{1}$ and $C_{2}$, and load $R_{20}$ is connected across capacitors $C_{1}^{\prime}$ and $C_{2}^{\prime}$.

The operation of a DSDO L-2L converter is sectioned into two modes: one when switch $S$ turn-ON and another when switch $S$ turn-OFF. Figure 8 shows the characteristic waveforms of voltage and current of the inductor for one switching cycle. In the characteristic waveform, time zone A-B describes the turn-ON time and time zone B-C describes the turn-OFF time.

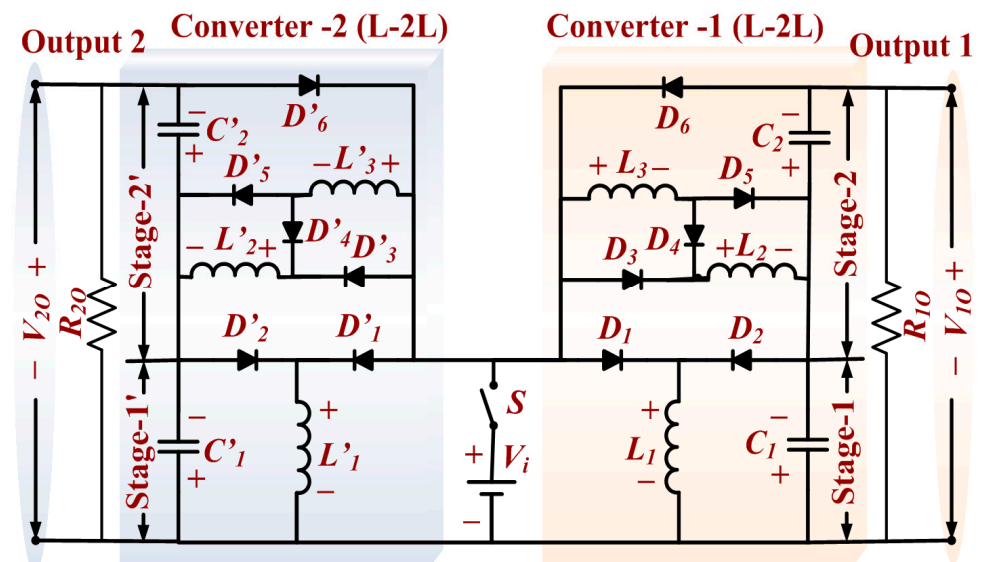

Figure 7. Power circuit of a DSDO L-2L converter.

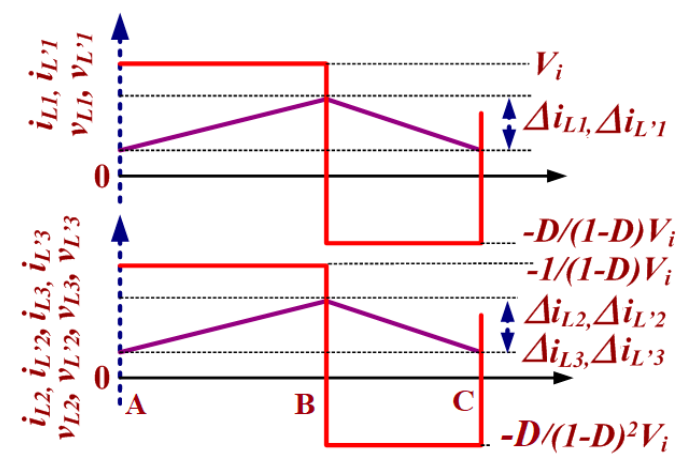

Figure 8. Waveforms of inductor voltage and current for a DSDO L-2L converter. 
The equivalent circuit for turn-ON mode is shown in Figure 9a. Inductor $L_{1}$ is magnetized by the input voltage $V_{i}$. In the same interval, the input voltage $V_{i}$ and voltage across capacitor $C_{1}$ magnetizes inductors $L_{2}$ and $L_{3}$. Energy is provided to load $R_{1 o}$ by capacitors $C_{1}$ and $C_{2}$. Inductor $L_{1}^{\prime}$ is magnetized by the input voltage $V_{i}$. In the same interval, the input voltage $V_{i}$ and voltage across capacitor $C^{\prime}{ }_{1}$ magnetize inductors $L_{2}^{\prime}$ and $L_{3}^{\prime}$. Energy is provided to load $R_{20}$ by capacitors $C^{\prime}{ }_{1}$ and $C^{\prime}{ }_{2}$. During turn-ON mode, capacitors $C_{1}, C_{1}^{\prime}{ }_{1}, C_{2}$, and $C_{2}^{\prime}$ are discharged, and inductors $L_{1}, L_{1}^{\prime}, L_{2}, L_{2}^{\prime}, L_{3}$, and $L_{3}^{\prime}$ are magnetized. In this mode, diodes $D_{1}, D^{\prime}{ }_{1}, D_{3}, D^{\prime}{ }_{3}, D_{5}$, and $D_{5}^{\prime}$ are forward biased and diodes $D_{2}$, $D_{2}^{\prime}, D_{4}, D^{\prime}{ }_{4}, D_{6}$, and $D_{6}^{\prime}$ are reverse biased.

The voltage across inductors can be obtained as follows,

$$
V_{L 1}=V_{L / 1}=V_{i} ; V_{L 2}=V_{L / 2}=V_{L 3}=V_{L / 3}=V_{C 1}+V_{i}
$$

The equivalent circuit of the turn-OFF mode of a DSDO L-2L converter is shown in Figure $9 \mathrm{~b}$. In this mode, capacitor $C_{1}$ is charged by the stored energy of inductor $L_{1}$. At same time, capacitor $C_{2}$ is charged by the series connection of inductors $L_{2}$ and $L_{3}$. Energy is provided to load $R_{10}$ by inductors $L_{1}, L_{2}$, and $L_{3}$. Capacitor $C^{\prime}{ }_{1}$ is charged by the stored energy of inductor $L_{1}^{\prime}$, whereas the capacitor $C^{\prime}{ }_{2}$ is charged by the series connection of inductors $L_{2}^{\prime}$ and $L_{3}^{\prime}$. Energy is provided to load $R_{20}$ by inductors $L_{1}^{\prime}{ }_{1}, L_{2}^{\prime}$, and $L_{3}^{\prime}$. In turn-OFF mode, capacitors $C_{1}, C_{1}^{\prime}, C_{2}$, and $C_{2}^{\prime}$ are charged and inductors $L_{1}, L_{1}^{\prime}, L_{2}, L_{2}^{\prime}, L_{3}$, and $L_{3}^{\prime}$ are demagnetized. In this mode, diodes $D_{1}, D^{\prime}{ }_{1}, D_{3}, D^{\prime}{ }_{3}, D_{5}$, and $D^{\prime}{ }_{5}$ are reverse biased and $D_{2}, D_{2}^{\prime}, D_{4}, D_{4}^{\prime}, D_{6}$, and $D_{6}^{\prime}$ are forward biased.

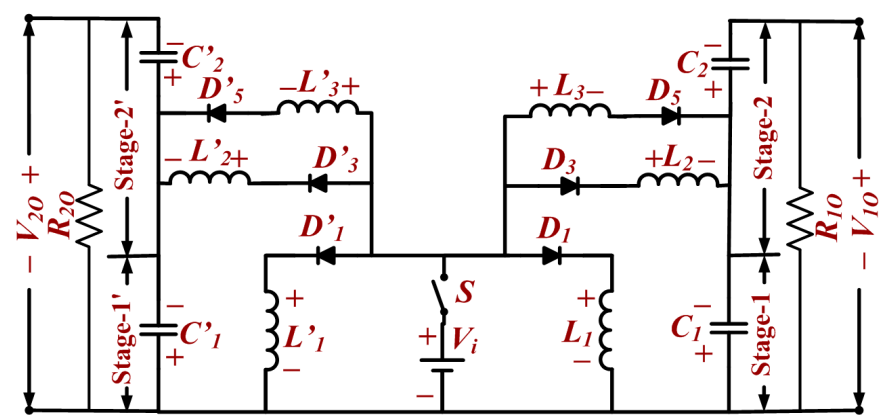

(a)

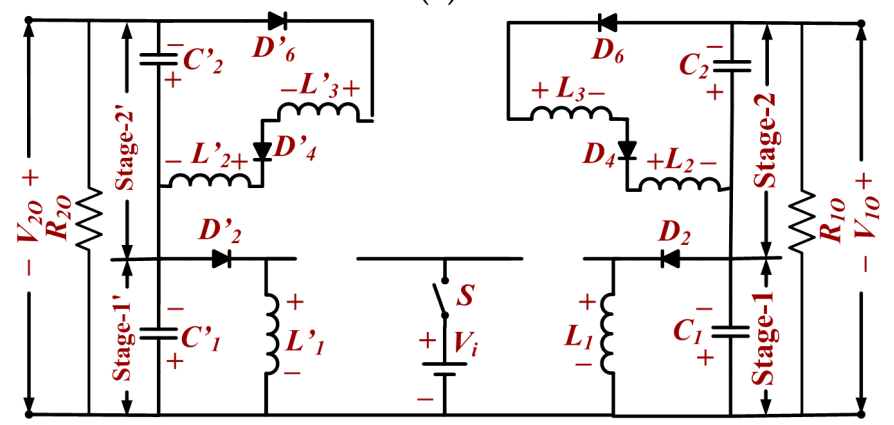

(b)

Figure 9. Equivalent circuitry of a DSDO L-2L converter: (a) ON mode; (b) OFF mode.

The voltage across inductors can be obtained as follows,

$$
V_{L 1}=V_{L / 1}=-V_{C 1} ; V_{L 2}=V_{L / 2}=V_{L 3}=V_{L / 3}=-V_{C 2} / 2
$$

The output voltages $V_{1 o}$ and $V_{2 o}$ are obtained as follows,

$$
\left.\begin{array}{rl}
\frac{V_{C 1}}{V_{i}} & =\frac{V_{C 1}}{V_{i}}=D(1-D)^{-1}, \frac{V_{C 2}}{V_{i}}=\frac{V_{C 12}}{V_{i}}=2 D(1-D)^{-2} \\
V_{10} & =V_{20}=-V_{i} \times\left(D(1-D)^{-1}+2 D(1-D)^{-2}\right)
\end{array}\right\}
$$




\subsection{DSDO L-2LC Converter}

Figure 10 illustrates the power circuit of a DSDO L-2LC converter. A single switch $S$ and input voltage $V_{i}$ are employed with two-stage L-2LC converters to obtain dual output voltages. The capacitors $C, C_{1}$, and $C_{2}$, inductors $L_{1}, L_{2}$, and $L_{3}$, diodes $D_{1}, D_{2}, \ldots$, and $D_{7}$ are elements of L-2LC converter-1. The capacitors $C^{\prime}, C^{\prime}{ }_{1}$, and $C_{2}^{\prime}$, inductors $L_{1}^{\prime}{ }_{1} L_{2}^{\prime}$, and $L_{3}^{\prime}$, diodes $D^{\prime}{ }_{1}, D_{2}^{\prime}{ }_{2}, \ldots$, and $D^{\prime}{ }_{7}$ are elements of L-2LC converter-2. The stage- 1 and stage- 2 voltages are taken across $C_{1}$ and $C_{2}$, respectively. The stage- $1^{\prime}$ and stage- $2^{\prime}$ voltages are taken across capacitors $C^{\prime}{ }_{1}$ and $C_{2}^{\prime}$, respectively. The load $R_{10}$ is connected across capacitors $C_{1}$ and $C_{2}$, and load $R_{2 o}$ is connected across capacitors $C_{1}^{\prime}$ and $C_{2}^{\prime}$.

The operation of a DSDO L-2LC converter is sectioned into two modes: one when switch $S$ turn-ON and another when switch $S$ turn-OFF. Figure 11 shows the characteristic waveforms of voltage and current of the inductor for one switching cycle. Time zone A-B describes the turn-ON time and time zone B-C describes the turn-OFF time of the switch. The equivalent circuit for turn-ON mode is shown in Figure 12a. In this interval, inductor $L_{1}$ is magnetized by the input voltage $V_{i}$. The input voltage $V_{i}$ and voltage across capacitor $C_{1}$ magnetize inductors $L_{2}$ and $L_{3}$, and charge capacitor $C$ in parallel. Energy is provided to load $R_{1 o}$ by capacitors $C_{1}$ and $C_{2}$. The inductor $L_{1}^{\prime}$ magnetized by the input voltage $V_{i}$. The input voltage $V_{i}$ and voltage across capacitor $C_{1}^{\prime}$ magnetize inductors $L_{2}^{\prime}$ and $L_{3}^{\prime}$ and charge the capacitor $C^{\prime}$ in parallel. Energy is provided to load $R_{20}$ by capacitors $C^{\prime}{ }_{1}$ and $C^{\prime}{ }_{2}$. In turn-ON mode, capacitors $C_{1}, C^{\prime}{ }_{1}, C_{2}$, and $C_{2}^{\prime}$ are discharged, capacitors $C$ and $C^{\prime}$ are charged, and inductors $L_{1}, L_{1}^{\prime}, L_{2}, L_{2}^{\prime}, L_{3}$, and $L^{\prime}{ }_{3}$ are magnetized. In this mode, diodes $D_{1}, D^{\prime}{ }_{1}, D_{3}, D^{\prime}{ }_{3}, D_{5}, D^{\prime}{ }_{5}, D_{6}$, and $D_{6}^{\prime}$ are forward biased and diodes $D_{2}, D_{2}^{\prime}, D_{4}, D^{\prime}{ }_{4}, D_{7}$, and $D^{\prime}{ }_{7}$ are reverse biased.

The voltages across the inductors are obtained as follows,

$$
V_{L 1}=V_{L / 1}=V_{i} ; V_{L 2}=V_{L 3}=V_{L / 2}=V_{L / 3}=V_{C 1}+V_{i}
$$

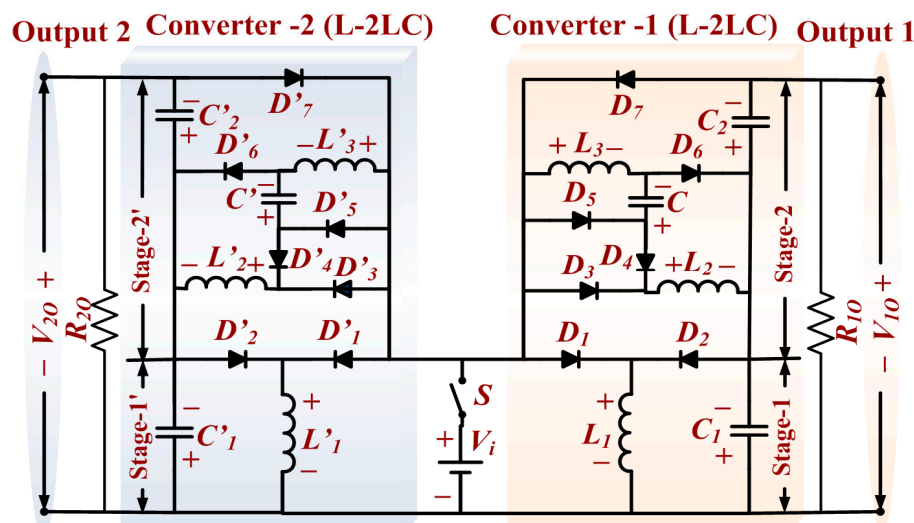

Figure 10. Power circuit of a DSDO L-2LC converter.

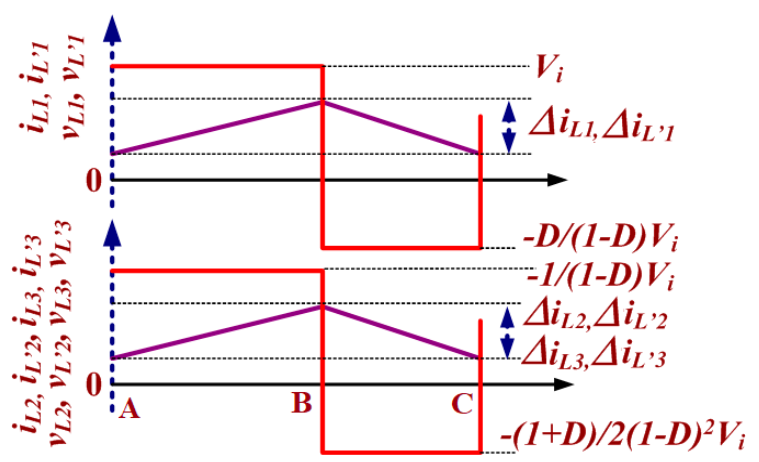

Figure 11. Waveforms of inductor voltage and current for a DSDO L-2LC converter. 


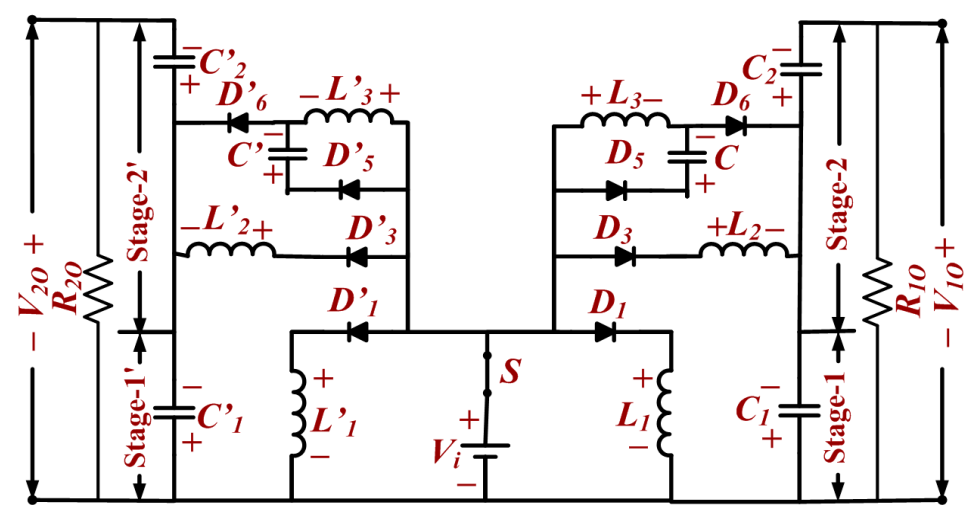

(a)

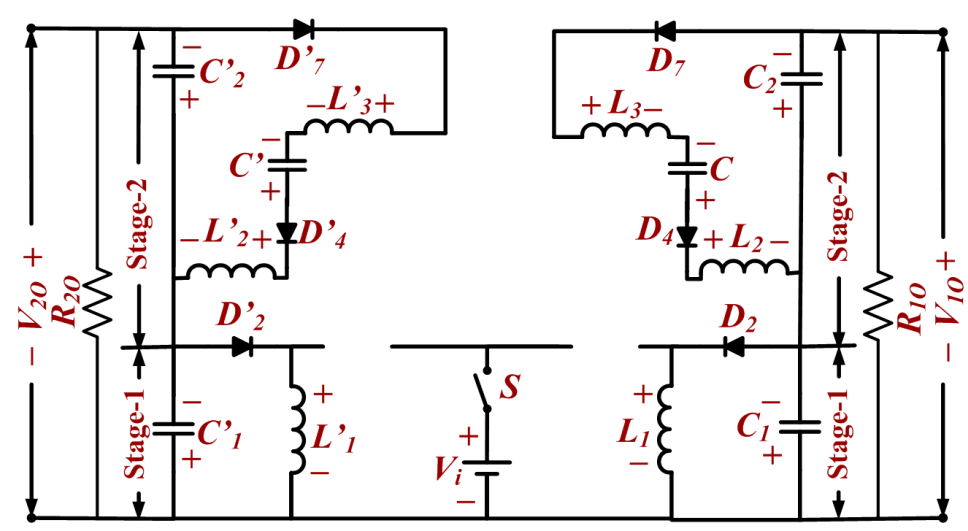

(b)

Figure 12. Equivalent circuitry of DSDO L-2LC converter: (a) ON mode; (b) OFF mode.

The equivalent circuit for turn-OFF mode of a DSDO L-2LC converter is shown in Figure 12b. The capacitor $C_{1}$ is charged by energy stored in inductor $L_{1}$. The capacitor $C_{2}$ is charged by the series connection of inductors $L_{2}, L_{3}$ and capacitor $C$. Energy is provided to load $R_{1 o}$ by inductors $L_{1}, L_{2}, L_{3}$, and capacitor $C$. The capacitor $C^{\prime}{ }_{1}$ is charged by stored energy of inductor $L_{1}^{\prime}$. The capacitor $C_{2}^{\prime}$ is charged by the series connection of inductors $L_{2}^{\prime}, L_{3}^{\prime}$, and capacitor $C^{\prime}$. Energy is provided to load $R_{20}$ by inductors $L_{1}^{\prime}, L_{2}^{\prime}, L_{3}^{\prime}$, and capacitor $C^{\prime}$. Hence, the capacitors $C_{1}, C^{\prime}{ }_{1}, C_{2}$, and $C_{2}^{\prime}$ are charged, capacitors $C$ and $C^{\prime}$ are discharged, and inductors $L_{1}, L_{1}^{\prime}, L_{2}, L_{2}^{\prime}, L_{3}$, and $L^{\prime}{ }_{3}$ are demagnetized. In this mode, diodes $D_{1}, D_{1}^{\prime}, D_{3}, D_{3}^{\prime}, D_{5}, D_{5}^{\prime}, D_{6}$, and $D_{6}^{\prime}$ are reverse biased and diodes $D_{2}, D_{2}^{\prime}, D_{4}, D_{4}^{\prime}, D_{7}$, and $D_{7}^{\prime}$ are forward biased.

The voltages across the inductors can be obtained as follows,

$$
V_{L 1}=V_{L \prime 1}=-V_{C 1} ;\left(V_{L 2}=V_{L \prime 2}=V_{L 3}=V_{L 3}\right)=\frac{-\left(V_{C 2}-V_{C}\right)}{2}=\frac{-\left(V_{C 2}-V_{C \prime}\right)}{2}
$$

The output voltages $V_{10}$ and $V_{20}$ are obtained as follows,

$$
\left.\begin{array}{l}
\frac{V_{C 1}}{V_{i}}=\frac{V_{C, 1}}{V_{i}}=D(1-D)^{-1}, \frac{V_{C 2}}{V_{i}}=\frac{V_{C, 2}}{V_{i}}=\frac{(1+D)}{(1-D)^{2}} \\
V_{10}=V_{2 o}=-V_{i} \times\left(D(1-D)^{-1}+(1+D)(1-D)^{-2}\right)
\end{array}\right\}
$$

\subsection{DSDO L-2LC $C_{m}$ Converter}

The DSDO L-2LC $m$ converter is a modified version of the DSDO L-2LC converter, obtained by eliminating two diodes. Figure 13 shows the power circuit of the DSDO L-2LC $\mathrm{C}_{\mathrm{m}}$ converter in which a single switch $S$ and input voltage $V_{i}$ are employed with two-stage $\mathrm{L}-2 \mathrm{~L} \mathrm{C}_{\mathrm{m}}$ converters to obtain dual 
output voltages. The capacitors $C, C_{1}$, and $C_{2}$, inductors $L_{1}, L_{2}$, and $L_{3}$, diodes $D_{1}, D_{2}, \ldots$, and $D_{5}$ are elements of $L-2 L C_{m}$ converter-1. The capacitors $C^{\prime}, C^{\prime}{ }_{1}$, and $C^{\prime}{ }_{2}$, inductors $L_{1}^{\prime}, L_{2}^{\prime}$, and $L^{\prime}{ }_{3}$, and diodes $D^{\prime}{ }_{1}, D_{2}^{\prime}{ }_{2}, \ldots$, and $D_{5}^{\prime}$ are elements of $\mathrm{L}-2 \mathrm{LC} \mathrm{C}_{\mathrm{m}}$ converter- 2 . The stage- 1 and stage- 2 voltages are taken across capacitors $C_{1}$ and $C_{2}$, respectively. The stage- $1^{\prime}$ and stage- $2^{\prime}$ voltages are taken across capacitors $C^{\prime}{ }_{1}$ and $C_{2}^{\prime}$, respectively. Load $R_{10}$ is connected across capacitors $C_{1}$ and $C_{2}$ and load $R_{20}$ is connected across capacitors $C_{1}^{\prime}$ and $C_{2}^{\prime}$.

The operation of a DSDO L-2LC $\mathrm{m}$ converter is sectioned into two modes: one when switch $S$ turn-ON and another when switch $S$ turn-OFF. Figure 14 shows the characteristic waveforms of voltage and current for inductors for one switching cycle. The time zone A-B describes the turn-ON time and $\mathrm{B}-\mathrm{C}$ describes the turn-OFF time. The equivalent circuit for turn-ON mode is shown in Figure 15a. The inductor $L_{1}$ is magnetized by the input voltage $V_{i}$. In the same interval, the inductor $V_{i}$ and voltage across capacitor $C_{1}$ magnetize inductors $L_{2}$ and $L_{3}$ and charge capacitor $C$ in parallel. The energy is provided to load $R_{10}$ by capacitors $C_{1}$ and $C_{2}$. The inductor $L_{1}^{\prime}$ magnetized by the input voltage $V_{i}$. In the same interval, input voltage $V_{i}$ and voltage across capacitor $C^{\prime}{ }_{1}$ magnetize inductors $L_{2}^{\prime}$ and $L_{3}^{\prime}$ and charge capacitor $C^{\prime}$ in parallel. The energy is provided to load $R_{20}$ by capacitors $C_{1}^{\prime}{ }_{1}$ and $C^{\prime}{ }_{2}$. Capacitors $C_{1}, C^{\prime}{ }_{1}, C_{2}$, and $C_{2}^{\prime}$ are discharged, capacitors $C$ and $C^{\prime}$ charged, and inductors $L_{1}, L_{1}^{\prime}, L_{2}$, $L_{2}^{\prime}{ }_{2}, L_{3}$, and $L_{3}^{\prime}{ }_{3}$ are magnetized. In this mode, diodes $D_{1}, D^{\prime}{ }_{1}, D_{3}, D^{\prime}{ }_{3}, D_{4}$, and $D^{\prime}{ }_{4}$ are forward biased and diodes $D_{2}, D_{2}^{\prime}, D_{5}$, and $D_{5}^{\prime}$ are reverse biased.

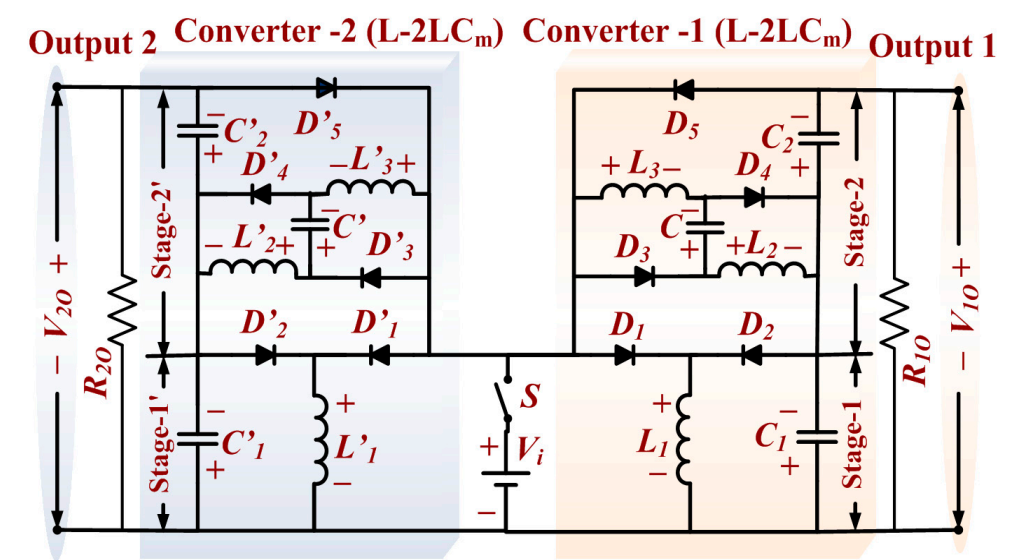

Figure 13. Power circuit of the DSDO L-2LC $m$ converter.

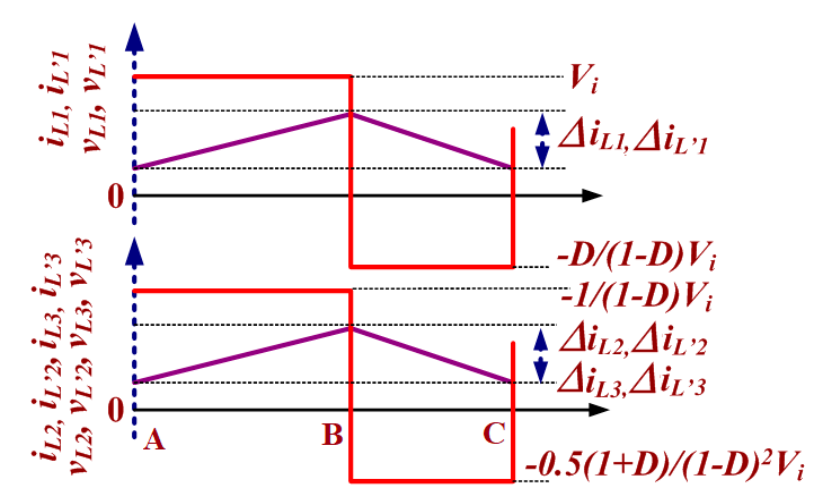

Figure 14. Waveforms of inductor voltage and current for a DSDO L-2LC $\mathrm{m}_{\mathrm{m}}$ converter.

The voltages across inductors can be obtained as follows,

$$
V_{L 1}=V_{L / 1}=V_{i} ; V_{L 2}=V_{L 3}=V_{L / 2}=V_{L / 3}=V_{C 1}+V_{i}
$$

The equivalent circuit for turn-OFF mode is shown in Figure $15 \mathrm{~b}$. Capacitor $C_{1}$ is charged by the energy of inductor $L_{1}$, and capacitor $C_{2}$ is charged by the series connection of inductors $L_{2}, L_{3}$ and 
capacitor $C$. Energy is provided to load $R_{10}$ by inductors $L_{1}, L_{2}, L_{3}$, and capacitor $C$. Capacitor $C^{\prime}{ }_{1}$ is charged by energy of inductor $L_{1}^{\prime}$. Capacitor $C_{2}^{\prime}$ is charged by the series connection of inductors $L_{2}^{\prime}$, $L^{\prime}{ }_{3}$ and capacitor $C^{\prime}$. Energy is provided to load $R_{20}$ by inductors $L_{1}^{\prime}, L_{2}^{\prime}{ }_{2}, L_{3}^{\prime}$, and capacitor $C^{\prime}$. The capacitors $C_{1}, C^{\prime}{ }_{1}, C_{2}$, and $C_{2}^{\prime}$ are charged, capacitors $C$ and $C^{\prime}$ are discharged, and inductors $L_{1}, L^{\prime}{ }_{1}^{\prime}$, $L_{2}, L_{2}^{\prime}, L_{3}$, and $L_{3}^{\prime}$ are demagnetized. Throughout this mode, diodes $D_{1}, D^{\prime}{ }_{1}, D_{3}, D^{\prime}{ }_{3}, D_{4}$, and $D^{\prime}{ }_{4}$ are reverse biased, and diodes $D_{2}, D_{2}^{\prime}, D_{5}$, and $D_{5}^{\prime}$ are forward biased.

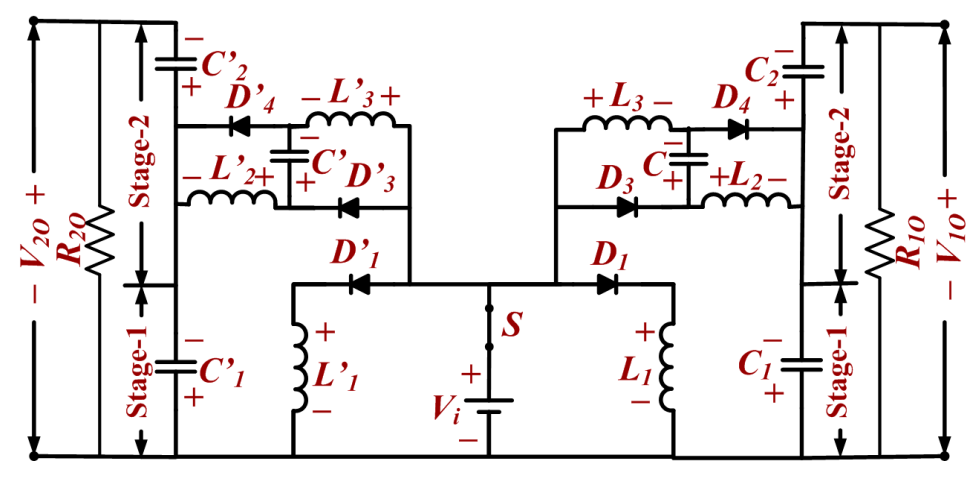

(a)

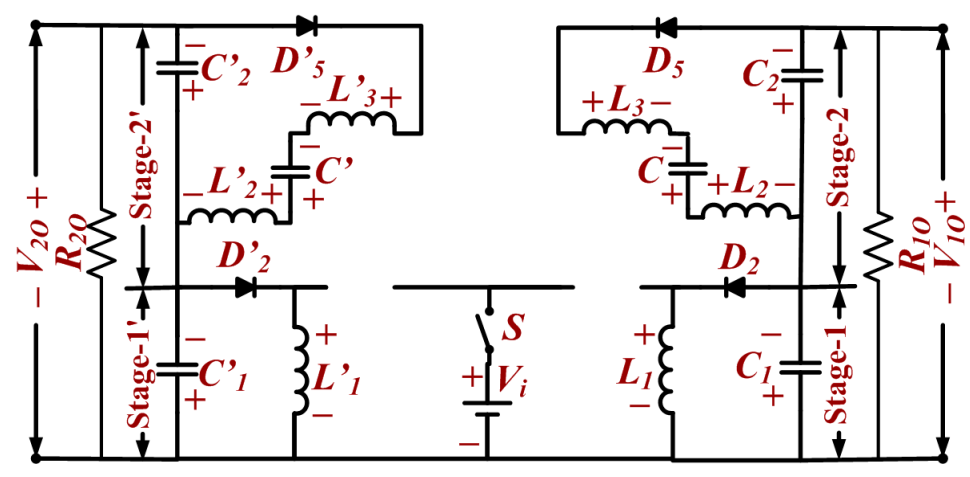

(b)

Figure 15. Equivalent circuitry of a DSDO L-2LC $m$ converter: (a) ON mode; (b) OFF mode.

The voltages across inductors can be obtained as follows,

$$
V_{L 1}=V_{L \prime 1}=-V_{C 1} ;\left(V_{L 2}=V_{L \prime 2}=V_{L 3}=V_{L 3}\right)=\frac{-\left(V_{C 2}-V_{C}\right)}{2}=\frac{-\left(V_{C 2}-V_{C \prime}\right)}{2}
$$

The output voltages $V_{10}$ and $V_{20}$ are obtained as follows,

$$
\left.\begin{array}{l}
\frac{V_{C 1}}{V_{i}}=\frac{V_{C 11}}{V_{i}}=D(1-D)^{-1}, \frac{V_{C 2}}{V_{i}}=\frac{V_{C 12}}{V_{i}}=\frac{(1+D)}{(1-D)^{2}} \\
V_{10}=V_{2 o}=-V_{i} \times\left(D(1-D)^{-1}+(1+D)(1-D)^{-2}\right)
\end{array}\right\}
$$

\section{Comparative Study}

In this section, the new DSDO converter configurations are compared with possible parallel combination of conventional converters and recently addressed DC-DC converters. Table 1 tabulates the comparison in terms of number of components and devices, voltage conversion ratio, and ratio of voltage across switch and input voltage. It is observed that one can achieve multiple output voltages by using conventional converters in parallel. However, the voltage conversion ratio is limited and not suitable for feeding high-voltage loads. Hybrid multiple output converters provide two different voltage levels while using common front-end structure. However, the voltage conversion ratio is not 
significantly improved by using a hybrid structure. The proposed converter provides a higher voltage conversion ratio compared to parallel combination of the conventional converters. In Figure 16a, the voltage conversion ratios of the converters are compared graphically. It is notable that all proposed converters provide inverting high voltage with medium duty cycle. It is observed that the DSDO $\mathrm{L}-2 \mathrm{LC}$ and DSDO $\mathrm{L}-2 \mathrm{LC}_{\mathrm{m}}$ converters generate higher voltage conversion ratios compared to the other proposed converters and in comparison to recent DC-DC converters. Figure 16b compares the number of diodes, control switches, inductors, and capacitors. It concludes that the DSDO L-2LC converter requires fewer diodes than the DSDO L-2LC converter, while both provide the same voltage conversion ratio.

Table 1. Comparison of Converters.

\begin{tabular}{|c|c|c|c|c|c|c|}
\hline Converter & Switches & Inductors & Diodes & Capacitors & $\begin{array}{c}\text { Voltage } \\
\text { Conversion } \\
\text { Ratio }\left(V_{1 o}, V_{2 o}\right)\end{array}$ & $\begin{array}{l}\text { Voltage Stress } \\
\text { across Switch } \\
\quad\left(V_{s} / V_{i}\right)\end{array}$ \\
\hline \multicolumn{7}{|c|}{ Converter without common front-end structure } \\
\hline $\begin{array}{l}\text { Boost-Boost converter } \\
\text { (Figure 1a) }\end{array}$ & 2 & 2 & 2 & 2 & 1/1-D, 1/1-D & $1 / 1-\mathrm{D}$ \\
\hline $\begin{array}{l}\text { Buck-Boost-Buck-Boost } \\
\text { converter (Figure 1b) }\end{array}$ & 2 & 2 & 2 & 2 & $-\mathrm{D} / 1-\mathrm{D},-\mathrm{D} / 1-\mathrm{D}$ & $1 / 1-\mathrm{D}$ \\
\hline $\begin{array}{l}\text { Cuk-Cuk Converter } \\
\text { (Figure 1c) }\end{array}$ & 2 & 4 & 2 & 4 & $-\mathrm{D} / 1-\mathrm{D},-\mathrm{D} / 1-\mathrm{D}$ & $1 / 1-\mathrm{D}$ \\
\hline $\begin{array}{c}\text { SEPIC-SEPIC } \\
\text { Converter (Figure 1d) }\end{array}$ & 2 & 4 & 2 & 4 & $\mathrm{D} / 1-\mathrm{D}, \mathrm{D} / 1-\mathrm{D}$ & $1 / 1-\mathrm{D}$ \\
\hline $\begin{array}{c}\text { ZETA-ZETA } \\
\text { Converter (Figure 1e) }\end{array}$ & 2 & 4 & 2 & 4 & $\mathrm{D} / 1-\mathrm{D}, \mathrm{D} / 1-\mathrm{D}$ & $1 / 1-\mathrm{D}$ \\
\hline \multicolumn{7}{|c|}{ Converter with common front-end structure } \\
\hline $\begin{array}{l}\text { Boost-Boost converter } \\
\text { (Figure 1f) }\end{array}$ & 1 & 1 & 2 & 2 & $1 / 1-\mathrm{D}, 1 / 1-\mathrm{D}$ & $1 / 1-\mathrm{D}$ \\
\hline $\begin{array}{l}\text { Buck-Boost-Buck-Boost } \\
\text { converter (Figure 1g) }\end{array}$ & 1 & 1 & 2 & 2 & $-\mathrm{D} / 1-\mathrm{D},-\mathrm{D} / 1-\mathrm{D}$ & $1 / 1-\mathrm{D}$ \\
\hline $\begin{array}{l}\text { Cuk-Cuk converter } \\
\text { (Figure 1h) }\end{array}$ & 1 & 3 & 2 & 4 & $-\mathrm{D} / 1-\mathrm{D},-\mathrm{D} / 1-\mathrm{D}$ & $1 / 1-\mathrm{D}$ \\
\hline $\begin{array}{c}\text { SEPIC-SEPIC } \\
\text { converter (Figure 1i) }\end{array}$ & 1 & 3 & 2 & 4 & $\mathrm{D} / 1-\mathrm{D}, \mathrm{D} / 1-\mathrm{D}$ & $1 / 1-\mathrm{D}$ \\
\hline $\begin{array}{c}\text { ZETA-ZETA } \\
\text { converter (Figure 1j) }\end{array}$ & 1 & 3 & 2 & 4 & $\mathrm{D} / 1-\mathrm{D}, \mathrm{D} / 1-\mathrm{D}$ & $1 / 1-\mathrm{D}$ \\
\hline \multicolumn{7}{|c|}{ Hybrid multi-output converter with common front-end structure } \\
\hline $\begin{array}{l}\text { SEPIC-Cuk converter } \\
\text { (Figure 2a) }\end{array}$ & 1 & 3 & 2 & 4 & -D/1-D, D/1-D & $1 / 1-\mathrm{D}$ \\
\hline $\begin{array}{l}\text { ZETA-Buck-boost } \\
\text { converter (Figure } 2 b \text { ) }\end{array}$ & 1 & 2 & 2 & 3 & $\mathrm{D} / 1-\mathrm{D},-\mathrm{D} / 1-\mathrm{D}$ & $1 / 1-\mathrm{D}$ \\
\hline $\begin{array}{l}\text { Boost-Cuk converter } \\
\text { (Figure 2c) }\end{array}$ & 1 & 2 & 2 & 3 & $-\mathrm{D} / 1-\mathrm{D}, 1 / 1-\mathrm{D}$ & $1 / 1-\mathrm{D}$ \\
\hline \multicolumn{7}{|c|}{ Proposed DSDO converter configurations } \\
\hline $\begin{array}{l}\text { DSDO L-L converters } \\
\text { (Figure 4) }\end{array}$ & 1 & 4 & 6 & 4 & $\begin{array}{l}\mathrm{D}(1-\mathrm{D})^{-1}+ \\
\mathrm{D}(1-\mathrm{D})^{-2}\end{array}$ & $\begin{array}{c}1+\mathrm{D}(1-\mathrm{D})^{-1}+ \\
\mathrm{D}(1-\mathrm{D})^{-2}\end{array}$ \\
\hline $\begin{array}{c}\text { DSDO L-2L } \\
\text { converters (Figure 7) }\end{array}$ & 1 & 6 & 12 & 4 & $\begin{array}{l}\mathrm{D}(1-\mathrm{D})^{-1}+ \\
2 \mathrm{D}(1-\mathrm{D})^{-2}\end{array}$ & $\begin{array}{c}1+\mathrm{D}(1-\mathrm{D})^{-1}+ \\
2 \mathrm{D}(1-\mathrm{D})^{-2}\end{array}$ \\
\hline $\begin{array}{c}\text { DSDO L-2LC } \\
\text { converters (Figure 10) }\end{array}$ & 1 & 6 & 14 & 6 & $\begin{array}{l}\mathrm{D}(1-\mathrm{D})^{-1}+(1+ \\
\mathrm{D})(1-\mathrm{D})^{-2}\end{array}$ & $\begin{array}{c}1+\mathrm{D}(1-\mathrm{D})^{-1}+(1+ \\
\mathrm{D})(1-\mathrm{D})^{-2}\end{array}$ \\
\hline $\begin{array}{c}\text { DSDO L-2LC } \\
\text { converters (Figure 13) }\end{array}$ & 1 & 6 & 10 & 6 & $\begin{array}{l}\mathrm{D}(1-\mathrm{D})^{-1}+(1+ \\
\mathrm{D})(1-\mathrm{D})^{-2}\end{array}$ & $\begin{array}{c}1+\mathrm{D}(1-\mathrm{D})^{-1}+(1+ \\
\mathrm{D})(1-\mathrm{D})^{-2}\end{array}$ \\
\hline
\end{tabular}




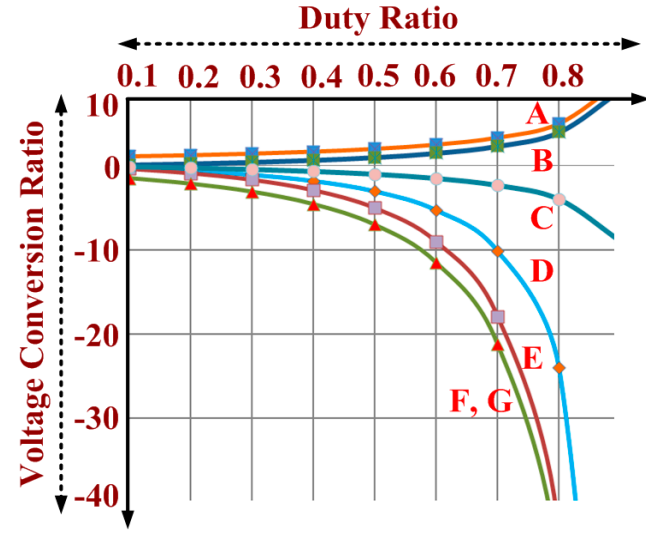

(a)

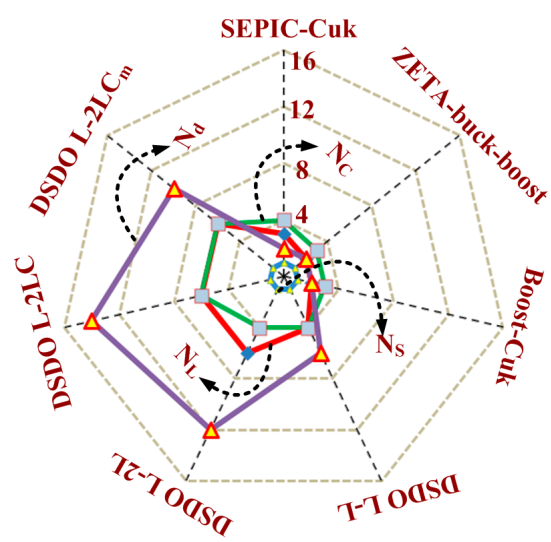

(b)

Figure 16. Comparison of (a) voltage conversion ratio versus duty cycle and (b) number of diodes $\left(N_{d}\right)$, number of capacitors $\left(N_{C}\right)$, number of Switches $\left(N_{S}\right)$, and number of inductors $\left(N_{L}\right)$. A: Boost, B: SEPIC,

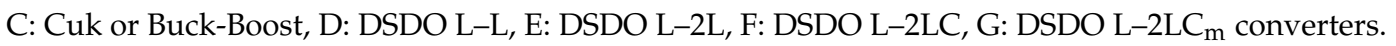

\section{Simulation and Experimental Results}

The principle and performance of the proposed DSDO converter configurations are validated through numerical simulation software. The converters were designed and tested with two loads, each rated to $100 \mathrm{~W}$ with a single input voltage of $20 \mathrm{~V}$ and with $25 \mathrm{kHz}$ switching frequency. For simulation and prototype hardware implementation, the values of the reactive components were $220 \mu \mathrm{F}$ for capacitors and $700 \mu \mathrm{H}$ for inductors.

DSDO L-L converter: Figure 17a shows the voltage across the two different loads $R_{10}$ and $R_{20}$. Voltage of $-105 \mathrm{~V}$ was generated across each load with a fixed $60 \%$ duty cycle. Figure $17 \mathrm{~b}, \mathrm{c}$ depicts the voltage across capacitors $C_{1}, C_{1}^{\prime}, C_{2}$, and $C_{2}^{\prime}$. The voltage magnitude across capacitors $C_{1}$ and $C_{1}^{\prime}$ are the same, i.e., $30 \mathrm{~V}$. The voltage magnitudes across capacitors $C_{2}$ and $C^{\prime}{ }_{2}$ are both $75 \mathrm{~V}$. Figure $17 \mathrm{~d}$ shows that the voltage across switch $S$ of a DSDO L-L converter is $125 \mathrm{~V}$. DSDO L-2L converter: Figure 18a shows the voltage across the two different loads $R_{10}$ and $R_{20}$. Voltage of $-180 \mathrm{~V}$ was generated across each load with a fixed $60 \%$ duty cycle. Figure $18 \mathrm{~b}, \mathrm{c}$ depicts the voltage across capacitors $C_{1}, C^{\prime}{ }_{1}$, $C_{2}$, and $C_{2}^{\prime}$, and shows that the voltage magnitude across capacitors $C_{1}$ and $C_{1}^{\prime}{ }_{1}$ is $30 \mathrm{~V}$. The voltage magnitudes across capacitors $C_{2}$ and $C_{2}^{\prime}$ are $150 \mathrm{~V}$. Figure $18 \mathrm{~d}$ shows that the voltage across switch $S$ of the DSDO L-2L converter is $200 \mathrm{~V}$. DSDO L-2LC converter: Figure 19a depicts the voltage across the two different loads $R_{1 o}$ and $R_{20}$. Voltage of $-230 \mathrm{~V}$ is generated across each load with a fixed $60 \%$ duty cycle. Figure $19 \mathrm{~b}, \mathrm{c}$ shows the waveforms of the voltage across capacitors $C_{1}, C_{1}^{\prime}, C_{2}$, and $C_{2}^{\prime}$. 


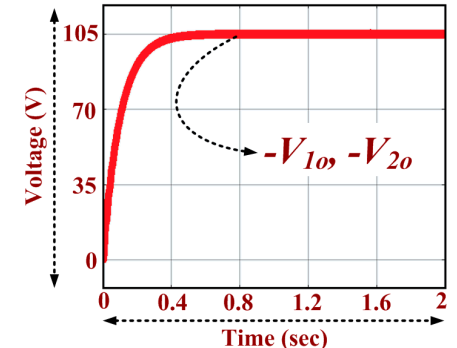

(a)

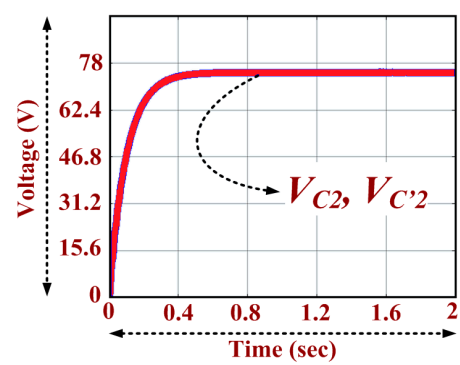

(c)

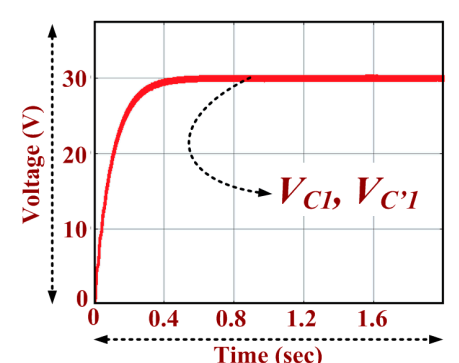

(b)

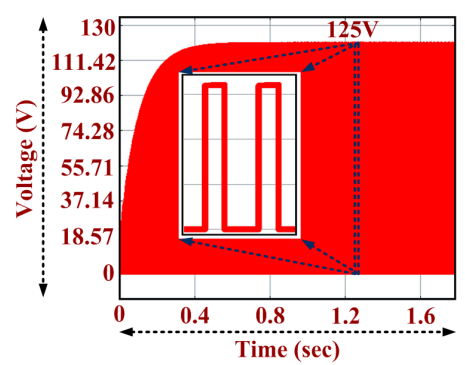

(d)

Figure 17. Simulation results of the DSDO L-L converter configuration: (a) Output voltages waveforms; (b) Voltage waveforms across stage-1 and stage-2; (c) Voltage waveforms across stage- $\mathbf{1}^{\prime}$ and stage-2'; (d) Voltage waveform across switch $S$.

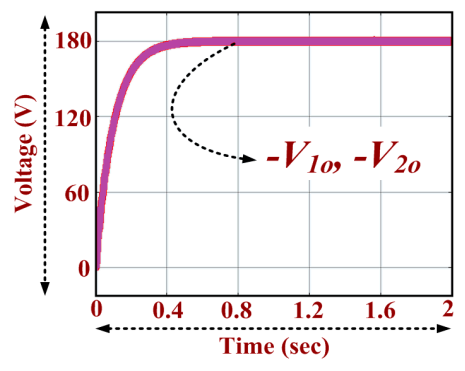

(a)

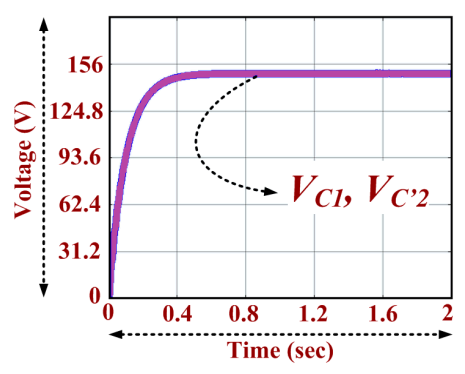

(c)

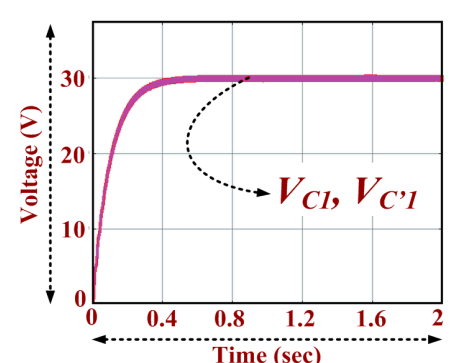

(b)

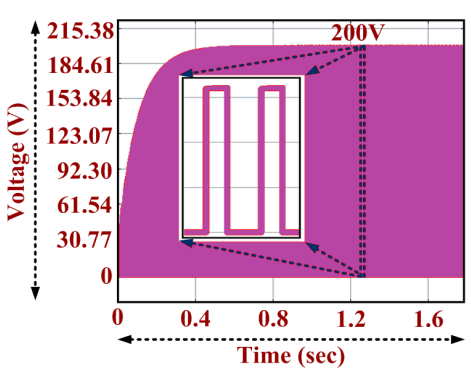

(d)

Figure 18. Simulation results of the DSDO L-2L converter configuration: (a) Output voltages waveforms; (b) Voltage waveforms at stage-1 and stage-2; (c) Voltage waveforms at stage- $1^{\prime}$ and stage- $2^{\prime}$; (d) Voltage waveform across switch $S$. 


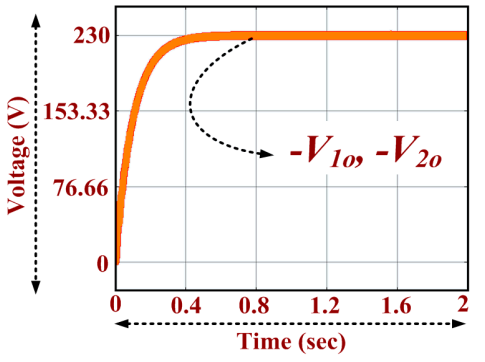

(a)

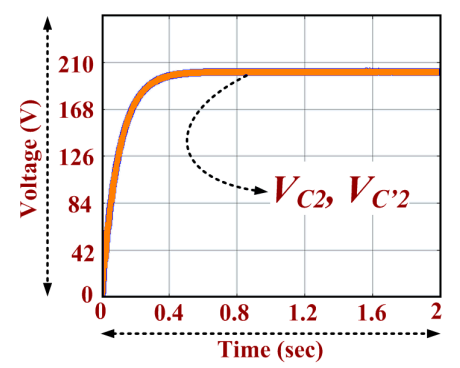

(c)

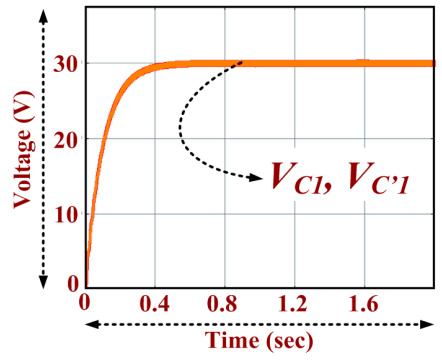

(b)

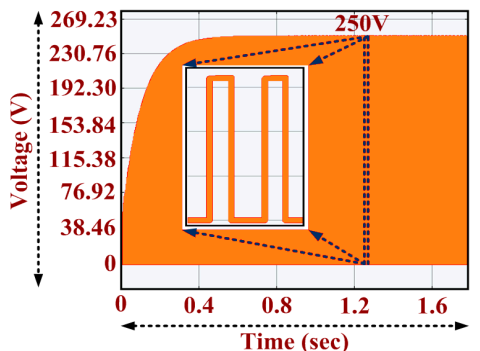

(d)

Figure 19. Simulation results of the DSDO L-2LC converter configuration: (a) Output voltages waveforms; (b) Voltage waveforms across stage-1 and Stage-2; (c) Voltage waveforms across stage- ' $^{\prime}$ and stage-2'; (d) Voltage across switch $S$.

The voltage magnitudes across capacitors $C_{1}$ and $C^{\prime}{ }_{1}$ are $30 \mathrm{~V}$ and the voltage across capacitors $C_{2}$ and $C^{\prime}{ }_{2}$ are $200 \mathrm{~V}$. Figure $19 \mathrm{~d}$ shows the voltage across switch $S$ of the DSDO L-2LC converter and its magnitude is $250 \mathrm{~V}$.

DSDO L-2LC $\mathrm{C}_{\mathrm{m}}$ converter: Figure 20a shows the waveforms of the voltage across the two different loads $R_{10}$ and $R_{20}$. Voltage of $-230 \mathrm{~V}$ is generated across each load with a fixed $60 \%$ duty cycle. Figure 20b,c shows the waveforms of the voltage across capacitors $C_{1}, C^{\prime}{ }_{1}, C_{2}$, and $C_{2}^{\prime}$. The voltage magnitudes across capacitors $C_{1}$ and $C_{1}^{\prime}$ are $30 \mathrm{~V}$, and voltage across capacitors $C_{2}$ and $C_{2}^{\prime}$ are $200 \mathrm{~V}$. Figure $20 \mathrm{~d}$ shows the voltage across switch $S$ of the DSDO L-2LC $\mathrm{m}_{\mathrm{m}}$ converter and its magnitude is $250 \mathrm{~V}$. Figure 21 shows the preliminary implemented hardware of the DSDO L-L converter. The designed hardware is tested with input voltage of $20 \mathrm{~V}$ and the output voltages are controlled at $-105 \mathrm{~V}$. Digitally controlled pulses are generated with the help of FPGA (Field Programmable Gate Array). Figures 22a and $22 \mathrm{~b}$ the voltages across $R_{1 o}$ and $R_{2 o}$ with the voltage of switch $S$, respectively. Using a $20 \mathrm{~V}$ input supply, $-104.2 \mathrm{~V}$ is successfully generated across each load and the voltage across switch $S$ is $124.08 \mathrm{~V}$. Figure 22c depicts the voltage and current waveform of inductors $L_{1}$ and $L_{2}$, respectively. In the ON state, the voltage across inductor $L_{1}$ is $20 \mathrm{~V}$, which confirms that inductor $L_{1}$ is magnetized with input voltage. In the OFF state, the voltage across inductor $L_{1}$ is $-30 \mathrm{~V}$, i.e., inductor $L_{1}$ is demagnetized to charge the capacitor $C_{1}$. In the ON state, the voltage across inductor $L_{2}$ is $50 \mathrm{~V}$, which confirms that the inductor $L_{2}$ is magnetized by the input voltage and the voltage across capacitor $C_{1}$. In the OFF state, the voltage across inductor $L_{2}$ is $-75 \mathrm{~V}$, i.e., inductor $L_{2}$ is demagnetized to charge capacitor $C_{2}$. Figure $22 \mathrm{~d}$ depicts the voltage and current waveforms of inductor $L_{1}^{\prime}, L_{2}^{\prime}$ respectively. In the ON state, the voltage across inductor $L_{1}^{\prime}$ is $20 \mathrm{~V}$, which confirms that inductor $L_{1}^{\prime}$ is magnetized by the input voltage. In the OFF state, the voltage across inductor $L_{1}^{\prime}$ is $-30 \mathrm{~V}$, i.e., inductor $L_{1}^{\prime}$ is demagnetized to charge capacitor $C^{\prime}{ }_{1}$. In the ON state, the voltage across inductor $L_{2}^{\prime}$ is $50 \mathrm{~V}$, which confirms that inductor $L_{2}^{\prime}$ is magnetized by the input voltage and the voltage across capacitor $C^{\prime}{ }_{1}$. In the OFF state, the voltage across inductor $L_{2}^{\prime}$ is $-75 \mathrm{~V}$, i.e., inductor $L_{2}^{\prime}$ is demagnetized to charge capacitor $C_{2}^{\prime}$. 


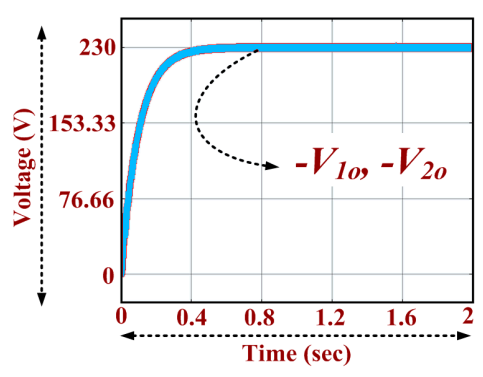

(a)

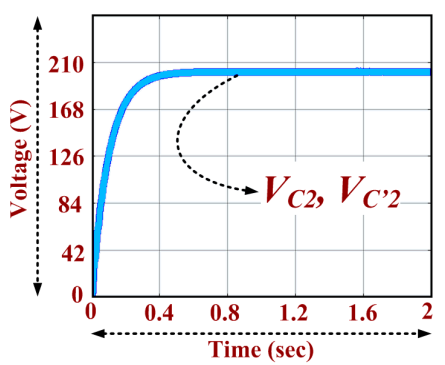

(c)

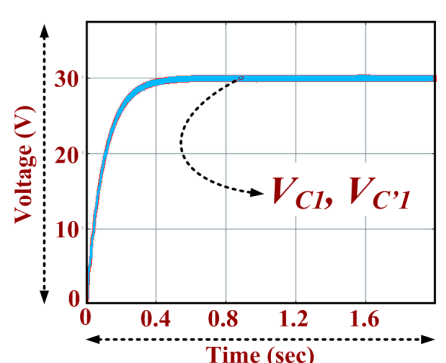

(b)

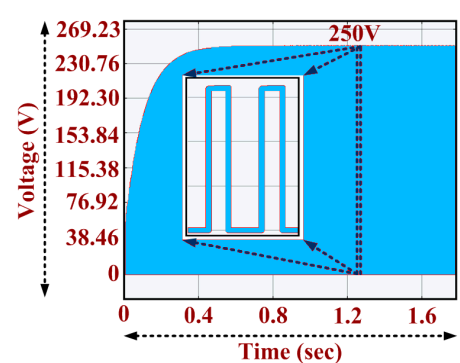

(d)

Figure 20. Simulation results of the DSDO L-2LC $\mathrm{m}_{\mathrm{m}}$ converter configuration: (a) Output voltages waveforms; (b) Voltage waveforms across stage-1 and Stage-2; (c) Voltage waveforms across stage- $1^{\prime}$ and stage- $2^{\prime} ;(\mathbf{d})$ Voltage across switch $S$.

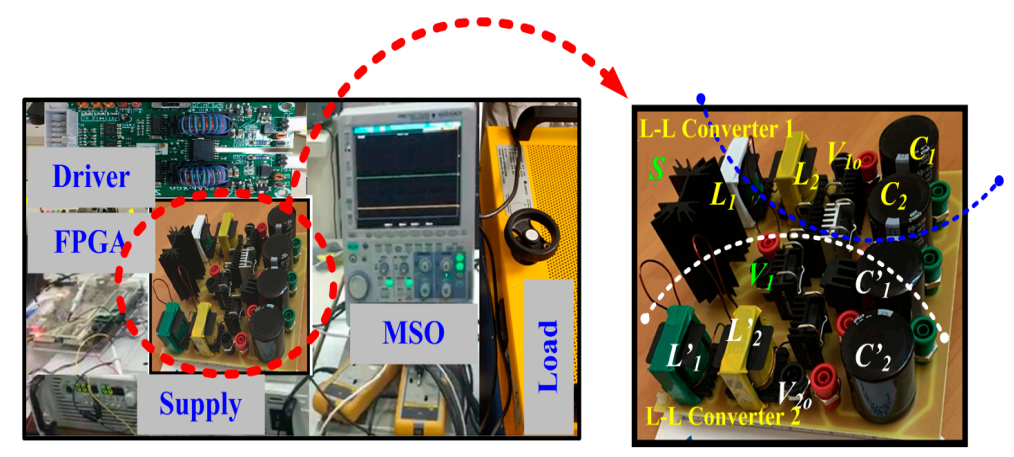

Figure 21. Experimental setup of the DSDO L-L converter configuration. 


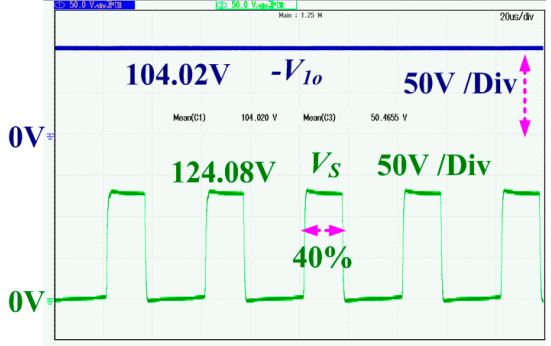

(a)

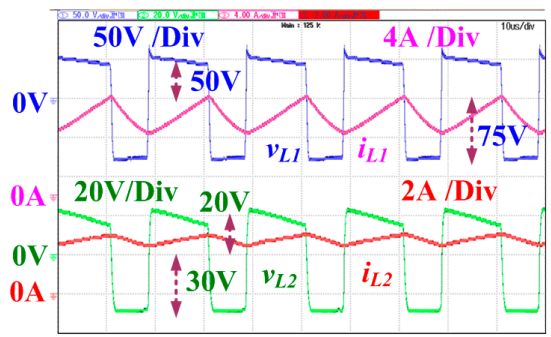

(c)

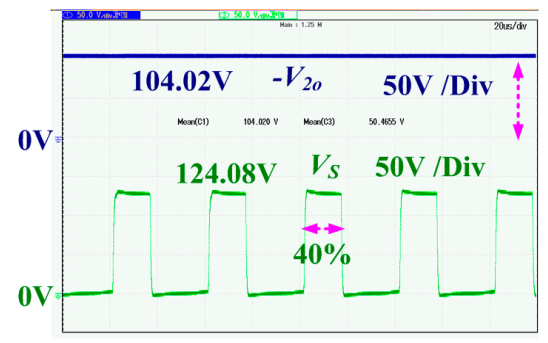

(b)

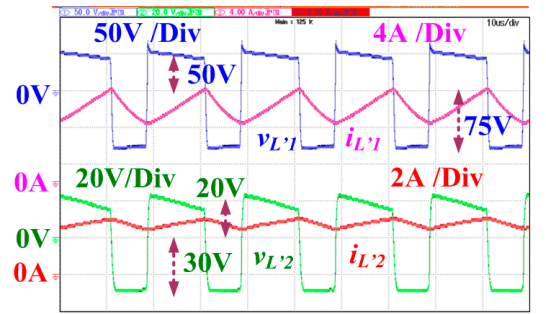

(d)

Figure 22. Experimental results of the DSDO L-L converter configuration: (a) voltage at load $R_{10}$ and voltage across switch $S$ waveforms; (b) voltage at load $R_{20}$ and voltage across switch $S$ waveforms; (c) inductor voltages and current of L converter-1; and (d) inductor voltages and current of L converter-2.

\section{Conclusions}

This article developed four DSDO converter configurations for high voltage fuel-cell electric vehicular loads. The proposed converters need a single controlling semiconductor switch and are able to feed two loads with high voltage conversion ratio. The circuitry of the DSDO L-L, DSDO L-2L, DSDO L-2LC, and DSDO L-2LC $m$ converters are developed by merging with two $\mathrm{L}-\mathrm{L}$, two $\mathrm{L}-2 \mathrm{~L}$, two $\mathrm{L}-2 \mathrm{LC}$, and two $\mathrm{L}-2 \mathrm{LC} \mathrm{C}_{\mathrm{m}}$ converters, respectively. The operating principles of the proposed converters are discussed with detailed theoretical analysis and governing equations for the output voltage conversion ratio. Finally, it is concluded that among the proposed converters, the DSDO L-2LC and DSDO L-2LC $\mathrm{C}_{m}$ converters provide higher output voltage and are effective in comparison with DC-DC converters. Both simulation and experimental results show that the proposed DSDO L-L converters had the expected performance.

Author Contributions: All authors contributed equally for the research work, to present the final manuscript as full research article in current version.

Funding: This research received no external funding.

Conflicts of Interest: The authors declare no conflict of interest.

\section{References}

1. Rezaee, S.; Farjah, E. A DC-DC Multiport Module for Integrating Plug-In Electric Vehicles in a Parking Lot: Topology and Operation. IEEE Trans. Power Electron 2014, 29, 5688-5695. [CrossRef]

2. Mercorelli, P.; Kubasiak, N.; Liu, S. Model predictive control of an electromagnetic actuator fed by multilevel PWM inverter. In Proceedings of the IEEE International Symposium on Industrial Electronics, Ajaccio, France, 4-7 May 2004; pp. 531-535.

3. Mercorelli, P.; Kubasiak, N.; Liu, S. Multilevel bridge governor by using model predictive control in wavelet packets for tracking trajectories. In Proceedings of the IEEE International Conference on Robotics and Automation, New Orleans, LA, USA, 26 April-1 May 2004; pp. 4079-4084. 
4. Faraji, R.; Adib, E.; Farzanehfard, H. Soft-switched non-isolated high step-up multi-port DC-DC converter for hybrid energy system with minimum number of switches. Intl. J. Electr. Power Energy Sys. 2019, 106, 511-519. [CrossRef]

5. Mercorelli, P. A Multilevel Inverter Bridge Control Structure with Energy Storage Using Model Predictive Control for Flat Systems. J. Eng. 2019, 1-15. [CrossRef]

6. Kubasiak, N.; Mercorelli, P.; Liu, S. Model Predictive Control of Transistor Pulse Converter for Feeding Electromagnetic Valve Actuator with Energy Storage. In Proceedings of the IEEE 44th Conference on Decision and Control, Seville, Spain, 12-15 December 2005; pp. 6794-6799.

7. Lucia, U. Overview on fuel cells. Renew. Sustain. Energy Rev. 2014, 30, 164-169. [CrossRef]

8. Peighambardoust, S.J.; Rowshanzamir, S.; Amjadi, M. Review of the proton exchange membranes for fuel cell applications. Intl. J. Hydrog. Energy 2010, 35, 9349-9384. [CrossRef]

9. Zhang, Z.; Pittini, R.; Andersen, M.A.E.; Thomsena, O.C. A Review and Design of Power Electronics Converters for Fuel Cell Hybrid System Applications. Energy Procedia 2012, 20, 301-310. [CrossRef]

10. Cheng, S.; Lo, Y.; Chiu, H.; Kuo, S. High-Efficiency Digital-Controlled Interleaved Power Converter for High-Power PEM Fuel-Cell Applications. IEEE Trans. Ind. Electron. 2013, 60, 773-780. [CrossRef]

11. Bhaskar, M.S.; Al-ammari, R.; Mohammad, M.; Padmanaban, S.; Iqbal, A. A New Triple-Switch-Triple-Mode High Step-Up Converter with Wide Range of Duty Cycle for DC Microgrid Applications. IEEE Trans. Ind. Appl. 2019, 1. [CrossRef]

12. Maroti, P.K.; Al-Ammari, R.; Bhaskar, M.S.; Meraj, M.; Iqbal, A.; Padmanaban, S.; Rahman, S. New tri-switching state non-isolated high gain DC-DC boost converter for microgrid application. IET Power Electron 2019, 12, 2741-2750. [CrossRef]

13. Yang, L.; Liang, T.; Chen, J. Transformerless DC-DC Converters with High Step-Up Voltage Gain. IEEE Trans. Ind. Electron. 2009, 56, 3144-3152. [CrossRef]

14. Bhaskar, M.S.; Meraj, M.; Iqbal, A.; Padmanaban, S.; Maroti, P.K.; Alammari, R. High Gain Transformer-Less Double-Duty-Triple-Mode DC/DC Converter for DC Microgrid. IEEE Access 2019, 7, 36353-36370. [CrossRef]

15. Muranda, C.; Ozsoy, E.; Padmanaban, S.; Bhaskar, M.S.; Fedak, V.; Ramachandaramurthy, V.K. Modified SEPIC DC-to-DC boost converter with high output-gain configuration for renewable applications. In Proceedings of the IEEE Conference on Energy Conversion CENCON'17, Kuala Lumpur, Malaysia, 30-31 October 2017; pp. 317-322.

16. Oluwafemi, A.W.; Ozsoy, E.; Padmanaban, S.; Bhaskar, M.S.; Ramachandaramurthy, V.K.; Fedak, V. A modified high output-gain cuk converter circuit configuration for renewable applications-A comprehensive investigation. In Proceedings of the IEEE Conference on Energy Conversion CENCON'17, Kuala Lumpur, Malaysia, 30-31 October 2017; pp. 117-122.

17. Morales-Saldana, A.; Gutierrez, E.E.C.; Leyva-Ramos, J. Modeling of switch-mode dc-dc cascade converters. IEEE Trans. Aerosp. Electron. Syst. 2002, 38, 295-299. [CrossRef]

18. Bhaskar, M.S.; Padmanaban, S.; Blaabjerg, F.; Wheeler, P.W. An Improved Multistage Switched Inductor Boost Converter (Improved M-SIBC) for Renewable Energy Applications: A key to Enhance Conversion Ratio. In Proceedings of the IEEE 19th Workshop on Control and Modeling for Power Electronics COMPEL'18, Padua, Italy, 25-28 June 2018.

19. De Novaes, Y.R.; Rufer, A.; Barbi, I. A New Quadratic, Three-Level, DC/DC Converter Suitable for Fuel Cell Applications. In Proceedings of the IEEE Power Conversion Conference-Nagoya, Nagoya, Japan, 2-5 April 2007; pp. 601-607.

20. Iqbal, A.; Bhaskar, M.S.; Meraj, M.; Padmanaban, S. DC-Transformer Modelling, Analysis and Comparison of the Experimental Investigation of a Non-Inverting and Non-Isolated Nx Multilevel Boost Converter (Nx MBC) for Low to High DC Voltage Applications. IEEE Access 2018, 6, 70935-70951. [CrossRef]

21. Iqbal, A.; Bhaskar, M.S.; Meraj, M.; Padmanaban, S.; Rahman, S. Closed-Loop Control and Boundary for CCM and DCM of Non-Isolated Inverting Nx Multilevel Boost Converter for High Voltage Step-Up Applications. IEEE Trans. Ind. Electron. 2019, 1. [CrossRef]

22. Bhaskar, M.S.; Padmanaban, S.; Blaabjerg, F. A Multistage DC-DC Step-Up Self-Balanced and Magnetic Component-Free Converter for Photovoltaic Applications: Hardware Implementation. Energies 2017, 10, 719. [CrossRef] 
23. Ranjana, M.S.B.; Alammari, R.; Meraj, M.; Iqbal, A.; Padmanaban, S. Modified Multilevel Buck-Boost Converter with Equal Voltage across Each Capacitor: Analysis and Experimental Investigations. IET Power Electron. 2019. [CrossRef]

24. Bhaskar, M.S.; Meraj, M.; Iqbal, A.; Padmanaban, S. Non-isolated Symmetrical Interleaved Multilevel Boost Converter with Reduction in Voltage Rating of Capacitors for High Voltage Microgrid Applications. IEEE Trans. Ind. Appl. 2019, 1. [CrossRef]

25. Tahan, M.; Bamgboje, D.; Hu, T. Flyback-Based Multiple Output dc-dc Converter with Independent Voltage Regulation. In Proceedings of the 9th IEEE International Symposium on Power Electronics for Distributed Generation Systems, PEDG, Charlotte, NC, USA, 25-28 June 2018; pp. 1-8.

26. Wai, R.J.; Liaw, J.J. High-Efficiency-Isolated Single-Input Multiple-Output Bidirectional Converter. IEEE Trans. Power Electron. 2015, 30, 4914-4930. [CrossRef]

27. Kim, J.K.; Choi, S.W.; Kim, C.E.; Moon, G.W. A New Standby Structure Using Multi-Output Full-Bridge Converter Integrating Flyback Converter. IEEE Trans. Ind. Electron. 2011, 58, 4763-4767. [CrossRef]

28. Ferrera, M.; Litrán, S.; Aranda, E.; Márquez, J.A. A Converter for Bipolar DC Link Based on SEPIC-Cuk Combination. IEEE Trans. Power Electron. 2015, 30, 6483-6487. [CrossRef]

29. Durán, E.; Litrán, S.P.; Ferrera, M.B.; Andújar, J.M. A Zeta-Buck-Boost converter combination for Single-Input Multiple-Output applications. In Proceedings of the 42nd Annual Conference of the IEEE Industrial Electronics Society, Florence, Italy, 23-26 October 2016; pp. 1251-1256.

30. Pires, V.F.; Foito, D.; Baptista, F.B.; Silva, J. A photovoltaic generator system with a DC/DC converter based on an integrated Boost-Ćuk topology. Sol. Energy 2016, 136, 1-9. [CrossRef]

31. Liu, X.; Xu, J.; Chen, Z.; Wang, N. Single-Inductor Dual-Output Buck-Boost Power Factor Correction Converter. IEEE Trans. Ind. Electron. 2015, 62, 943-952. [CrossRef]

32. Sanjeevikumar, P.; Bhaskar, M.S.; Dhond, P.; Blaabjerg, F.; Pecht, M. Non-isolated Sextuple Output Hybrid Triad Converter Configurations for High Step-Up Renewable Energy Applications. In Power Systems and Energy Management; Springer: Berlin/Heidelberg, Germany, 2018; pp. 1-12.

33. Patra, P.; Patra, A.; Misra, N. A Single-Inductor Multiple-Output Switcher with Simultaneous Buck, Boost, and Inverted Outputs. IEEE Trans. Power Electron. 2011, 27, 1936-1951. [CrossRef]

34. Bhaskar, M.S.; Padmanaban, S.; Kulkarni, R.; Blaabjerg, F.; Seshagiri, S.; Hajizadeh, A. Novel LY converter topologies for high gain transfer ratio: A new breed of XY family. In Proceedings of the 4th IET Clean Energy and Technology Conference, IET-CEAT, Kuala Lumpur, Malaysia, 14-15 November 2016; pp. 1-8.

35. Mahajan, S.B.; Sanjeevikumar, P.; Wheeler, P.; Blaabjerg, F.; Rivera, M.; Kulkarni, R. X-Y converter family: A new breed of buck boost converter for high step-up renewable energy applications. In Proceedings of the IEEE International Conference on Automatica IEEE-ICA-ACCA, Curico, Chile, 19-21 October 2016; pp. 1-8.

36. Bhaskar, M.S.; Sanjeevikumar, P.; Iqbal, A.; Meraj, M.; Howeldar, A.; Kamuruzzaman, J. L-L Converter for Fuel Cell Vehicular Power Train Applications: Hardware Implementation of Primary Member of X-Y Converter Family. In Proceedings of the IEEE Power Electronics, Drives and Energy Systems PEDES'18, Chennai, India, 18-21 December 2018.

37. Maroti, P.K.; Padmanaban, S.; Bhaskar, M.S.; Blaabjerg, F.; Ramachandaramurthy, K.V.; Siano, P.; Fedak, V. A novel 2L-Y DC-DC converter topologies for high conversion ratio renewable application. In Proceedings of the IEEE Conference on Energy Conversion CENCON'17, Kuala Lumpur, Malaysia, 30 October 2017; pp. 323-328.

38. Padmanaban, S.; Bhaskar, M.S.; Blaabjerg, F.; Yang, Y. A New DC-DC Multilevel Breed of XY Converter Family for Renewable Energy Applications: LY Multilevel Structured Boost Converter. In Proceedings of the 44th Annual Conference of the IEEE Industrial Electronics Society, Washington, DC, USA, 21-23 October 2018; pp. 6110-6115.

(C) 2019 by the authors. Licensee MDPI, Basel, Switzerland. This article is an open access article distributed under the terms and conditions of the Creative Commons Attribution (CC BY) license (http://creativecommons.org/licenses/by/4.0/). 